\title{
Short Selling Pressure, Stock Price Behavior, and Management Forecast Precision: Evidence from a Natural Experiment
}

\author{
Yinghua Li \\ Associate Professor \\ School of Accountancy, Arizona State University \\ Email: yinghua.li@asu.edu \\ Tel: (480) 965-5188 \\ Liandong Zhang \\ Associate Professor \\ Department of Accountancy, City University of Hong Kong \\ Email: liandong.zhang@cityu.edu.hk \\ Tel: (852) 3442-7843
}

November 2014

Forthcoming, Journal of Accounting Research

Accepted by Christian Leuz. We appreciate helpful comments from two anonymous reviewers, Jong-Hag Choi, Kalin Kolev, Bin Miao, and Gord Richardson. We thank Ke Wang for research assistance. An online appendix to this paper can be downloaded at http://research.chicagobooth.edu/arc/journal/onlineappendices.aspx. 


\title{
Short Selling Pressure, Stock Price Behavior, and Management Forecast Precision: Evidence from a Natural Experiment
}

\begin{abstract}
Using a natural experiment (Regulation SHO), we show that short selling pressure and consequent stock price behavior have a causal effect on managers' voluntary disclosure choices. Specifically, we find that managers respond to a positive exogenous shock to short selling pressure and price sensitivity to bad news by reducing the precision of bad news forecasts. This finding on management forecasts appears to be generalizable to other corporate disclosures. In particular, we find that, in response to increased short selling pressure, managers also reduce the readability (or increase the fuzziness) of bad news annual reports. Overall, our results suggest that maintaining the current level of stock prices is an important consideration in managers' strategic disclosure decisions.
\end{abstract}

Keywords: Regulation SHO, short selling, corporate disclosure, forecast precision, annual report readability, managerial incentives

JEL Codes: D82; G14; G18; M41 


\section{Introduction}

Corporate executives pay considerable attention to secondary market prices and they have strong incentives to maintain or increase their firms' stock prices. The accounting literature argues that managers can make strategic financial reporting or disclosure choices to influence stock prices (e.g., Healy and Palepu [2001]). A large body of empirical research examines whether and how corporate disclosures affect stock prices. The literature, however, provides little directional evidence on whether the behavior of stock prices has a causal effect on managerial strategic disclosure decisions. The difficulty in establishing causality stems largely from the endogenous nature of stock prices. In this paper, we use a natural experiment to examine the causal effect of stock price behavior on managers' voluntary disclosure choices. Specifically, we examine the effect of an exogenous shock to short selling pressure and consequent price sensitivity to bad news on management forecast precision, where precision refers to the specificity of forecasts. ${ }^{1}$

We focus on management forecasts and their precision for the following reasons. First, management forecasts are an important source of corporate financial information for investors. For example, Beyer et al. [2010] show that management forecasts provide, on average, approximately 55\% of accounting-based information to the stock market over the 1994 to 2007 period. Thus, it is important to understand factors that affect management forecast choices. Second, there is a large degree of variation in forecast precision, and managers have a great deal of control and discretion over forecast precision (Hirst et al. [2008]). Once the decision to issue a forecast is made, managers can issue either qualitative or quantitative forecasts. Quantitative

\footnotetext{
${ }^{1}$ Our study focuses on one specific aspect of stock price behavior, price sensitivity to bad news, as dictated by our experimental setting.
} 
forecasts can be made as point, range, minimum, or maximum estimates. For range forecasts, managers can further choose their width. Due to litigation or reputation concerns, managers may have even greater discretion over forecast precision than over the decision of whether to issue a forecast (Cheng et al. [2013], Skinner [1994]). Thus, forecast precision is an ideal setting in which to test managers' strategic disclosure choices. Finally, prior research shows that forecast precision has a significant effect on the sensitivity of market prices to forecast news (e.g., Baginski et al. [1993]). This effect makes the choice of forecast precision a natural fit in our controlled experiment, as discussed below.

Our experiment is based on Securities and Exchange Commission (SEC) Regulation SHO (Reg SHO), adopted in 2005. On September 7, 2004, the SEC passed Reg SHO, which mandated temporary suspension of short-sale price tests for a set of randomly selected pilot stocks during the period May 2, 2005 to August 6, 2007. The pilot stocks comprise every third stock of the Russell 3000 Index ranked by average daily trading volume. The suspension of short-sale price tests (i.e., the uptick test for the NYSE and the bid test for the NASDAQ) represents an exogenous decrease in short-sale constraints, leading to an increase in short selling activities for the pilot stocks (e.g., SEC [2007], Diether et al. [2009]). Increased trading activities of pessimistic investors make prices of the pilot stocks more sensitive to negative news (e.g., Goldstein and Guembel [2008], Grullon et al. [2012]).

This study predicts that managers of pilot firms, in response to the positive shock to price sensitivity to bad news, reduce the precision of bad news forecasts to maintain the current level of stock prices. ${ }^{2}$ This prediction is based on the theory and evidence that the magnitude of price

\footnotetext{
${ }^{2}$ According to a 2008 NYSE survey, managers appear to be aware of and sensitive to the impact of eliminating price tests on the amount of short-selling in their firms (Grullon et al. [2012], Fang et al. [2013]). They also should have known whether their firms were selected for the experiment given the public disclosure of the list of pilot securities
} 
reaction to a disclosed signal is positively related to its precision (e.g., Kim and Verrecchia [1991], Baginski et al. [1993], Baginski et al. [2007]). In fact, our conjecture requires only that managers believe that reducing the precision of bad news can minimize its impact on stock prices. This assumption appears to be true given the survey evidence that some CFOs admit that they tend to make fuzzy disclosures if the news is bad (Graham et al. [2005]).

To conduct our empirical tests, we first obtain a list of the 2004 and 2005 Russell 3000 Index constituents from Russell Investments. The pilot stocks chosen by the SEC are naturally our treatment stocks. We then assign the remaining stocks of the Russell 3000 Index to the control group. The sample period covers eight quarters before and eight quarters after the adoption date of Reg SHO (i.e., May 2, 2005). Following Cheng et al. [2013], we focus on point and range forecasts from the First Call Database, because the calculation and classification of forecast news is more straightforward for these forecasts. Before conducting our main tests, we first examine whether Reg SHO affects stock market reaction to management forecast news. Consistent with the idea that short-sale constraints hinder incorporation of bad news into prices, we find that stock prices of the pilot firms become significantly more sensitive to negative forecast news after Reg SHO. In contrast, we find no meaningful or much smaller changes in price reactions to negative news for stocks in the control group. Moreover, stock price sensitivity to good news forecasts changes for neither the pilot nor the control stocks. These results suggest that Reg SHO is an exogenous shock to price sensitivity to bad news forecasts.

Taking Reg SHO as an exogenous shock to stock price behavior, we examine whether

on the SEC's website several months before implementation of Reg SHO and the extensive financial media coverage of the experiment. 
stock price behavior has a causal effect on managerial choice of forecast precision. ${ }^{3}$ We measure forecast precision as the negative of forecast width (with point estimates assigned a zero width). Using a difference-in-differences regression approach, we find that the pilot firms significantly reduce their bad news forecast precision by about $17 \%$ relative to the control group upon adoption of Reg SHO, consistent with our prediction. Thus, it appears that managers act strategically to minimize the adverse effect of short selling pressure on stock prices. This result is robust to controlling for a battery of other determinants of forecast precision, such as firm size, return volatility, litigation risk, analyst coverage, institutional ownership, forecast horizon, and the magnitude of forecast surprise, as well as firm and time fixed effects. Moreover, we find no significant differences in changes in good news forecast precision between the treatment and control groups. This null result for good news forecasts essentially lends additional credence to the causal effect of short selling pressure and consequent price behavior on management disclosure choices.

We next examine whether our main findings are generalizable to other corporate disclosures. Bloomfield [2002] argues that managers can reduce the market response to bad news by making bad news more costly to analyze. Therefore, we conjecture that managers may also respond to increased short selling pressure by increasing the obscurity of their bad news financial reports. Consistent with this conjecture, we show that pilot firms with bad earnings news also reduce the readability (or increase the fogginess) of their annual reports around implementation of Reg SHO. This result provides some corroborating evidence for our main thesis that managers respond to increased short selling pressure by reducing the precision (or increasing the fuzziness)

\footnotetext{
${ }^{3}$ If managers respond to Reg SHO by stopping bad news forecasts, our empirical tests on forecast precision may suffer from self-selection bias. Empirically, however, we find no evidence that managers forgo bad news forecasts upon implementation of Reg SHO. We offer more detailed discussions on this issue in Section 4.2.
} 
of bad news disclosures.

Further, we conduct several additional tests. First, we find no evidence that Reg SHO affects the magnitude (or direction) of management forecast news or the accuracy (or bias) of management forecasts. Second, we show that the significant reductions in bad news forecast precision among pilot firms are concentrated in the second half of the post-Reg SHO period. Moreover, we find that pilot firms reduce their forecast precision to a greater extent during the second half of the treatment period if their industry peers reduce their forecast precision more during the first half of the treatment period, suggesting intra-industry learning. Finally, we find that the effect of short selling pressure on bad news forecast precision is more pronounced for smaller firms, firms with higher CFO compensation portfolio sensitivity to stock prices, firms with lower analyst following, and firms experiencing a larger increase in price sensitivity to earnings news after Reg SHO.

Our study is related to several strands of literature. First, it contributes to the broader accounting literature on managerial strategic reporting and disclosure choices. ${ }^{4}$ The accounting literature has long recognized that maintaining or increasing stock prices is one of the most important considerations in managers' reporting and disclosure decisions. However, although there are many studies examining the effect of disclosure on stock prices, we are not aware of prior research that provides direct causal evidence of the effect of stock price behavior on managerial disclosure choices. Our study fills this void by showing a causal effect of short selling pressure and consequent stock price behavior on management forecast precision.

Moreover, our analysis shows that managers also respond to the positive shock to price

\footnotetext{
${ }^{4}$ See Beyer et al. [2010] and Healy and Palepu [2001] for more detailed discussions of this literature.
} 
sensitivity to bad news by reducing the readability of their bad news annual reports. In a related study, Li [2008] argues that investors react less completely to information that is less easily extracted from public disclosures and finds that firms with poor performance provide annual reports that are harder to read. Our results complement Li [2008] by documenting a causal effect of stock price behavior on the fuzziness of annual report disclosures.

Second, our study is part of the emerging literature on the real effects of secondary financial markets. Bond et al. [2012] argue that the secondary stock market is not just a sideshow, but rather has an effect on the real decisions of managers. For example, Edmans et al. [2012] show a strong causal effect of stock prices on takeover activities. Consistent with the idea that stock prices have real effects, our study shows that short selling pressure in the stock market has a causal effect on managers' disclosure decisions.

Third, our study adds to the literature on the determinants of management forecast precision. Prior research examines the effects of various firm-level characteristics on management forecast precision. ${ }^{5}$ Our study extends this line of research by identifying short selling pressure and consequent price sensitivity to bad news as a significant determinant of forecast precision. Perhaps more importantly, while most prior studies are association research, which suffers from endogeneity issues, our paper is one of the first to use a natural experiment to provide casual evidence on the determinants of management forecast precision.

Finally, our study provides additional evidence on the effect of short selling regulation. Recent research examines the effect of Reg SHO on short selling activities and market quality (Diether et al. [2009]), corporate financing and investment decisions (Grullon et al. [2012]), the

\footnotetext{
${ }^{5}$ See Hirst et al. [2008] for a survey of this literature.
} 
design of CEO compensation contracts (Angelis et al. [2013]), and earnings management (Fang et al. [2013]). Our study contributes to this line of research by examining the effect of Reg SHO on corporate voluntary disclosure decisions.

The remainder of this paper proceeds as follows. Section 2 reviews the related literature and develops empirical predictions. Section 3 describes the data and measurement of key variables. Section 4 presents the main empirical analyses and robustness checks. In Section 5, we conduct several cross-sectional analyses. Section 6 sets forth our conclusions.

\section{Literature Review and Empirical Predictions}

Corporate managers have an information advantage over outside investors regarding the profitability and growth of their firms, and they have incentives to maximize investor perception of firm value as reflected by stock prices (e.g., Beyer et al. [2010]). Management earnings forecasts are one of the key disclosure mechanisms that managers use to convey information and influence market prices. A number of studies provide evidence that the stock market reacts to management forecast news, suggesting that investors perceive these disclosures to be informative. ${ }^{6}$ Beyer et al. [2010] estimate that, for the average firm, $15.67 \%$ of quarterly stock return variance occurs on days when management forecasts are made, representing $55.23 \%$ of the return variances explained by all types of accounting disclosure.

Given the significant influence of management forecasts on investor decisions, it is critical to understand what factors affect managers' forecast choices (Healy and Palepu [2001]). While a large body of research examines the propensity or frequency of earnings forecasts, Hirst et al. [2008] argue that managers have greater discretion over forecast characteristics than over

\footnotetext{
${ }^{6}$ See Patell [1976], Penman [1980], Waymire [1984], Baginski and Hassell [1990], Pownall et al. [1993], Baginski et al. [1993, 2004], Hutton et al. [2003], and Hutton and Stocken [2007], among others.
} 
the decision of whether to issue a forecast; these authors call for more research on the determinants of forecast characteristics. As discussed in the introduction, the main focus of our study is management forecast precision. The literature shows that several firm characteristics are associated with forecast precision. For example, Baginski and Hassell [1997] find that managers produce more precise earnings forecasts for firms with greater analyst following and for smaller firms. Bamber and Cheon [1998] show that exposure to legal liability is negatively related to forecast precision. Baginski et al. [2002] find that Canadian managers issue more precise forecasts than their US counterparts, consistent with the legal environment affecting forecast precision. Ajinkya et al. [2005] find that firms with more outside directors and higher institutional ownership produce more precise forecasts, suggesting that superior governance is associated with greater forecast precision. In contrast, Karamanou and Vafeas [2005] find that more effective boards and audit committees are associated with less precise forecasts. Skinner [1994] and Choi et al. [2010] find that management forecasts of negative news are less precise. Finally, Cheng et al. [2013] show that managers choose forecast precision strategically to maximize insider trading profits.

In reviewing the corporate disclosure literature, Healy and Palepu [2001] and Beyer et al. [2010] recognize that a significant challenge facing this body of literature is the issue of causality or endogeneity. These authors recommend that researchers identify research design settings in which an exogenous shock can be used to study the causal relations between corporate disclosures and their environments. Following this recommendation, our study extends the literature on management forecasts by investigating the effect of an exogenous shock to short selling pressure on management forecast precision. In doing so, we intend to shed light on the causal effect of stock price behavior on managers’ strategic disclosure decisions. 
The exogenous shock is brought about by Reg SHO’s Pilot Program. On May 2, 2005, the SEC implemented Reg SHO, which suspended the short-sale price tests for a random sample of pilot stocks. Reg SHO significantly relaxed the short-sale constraints on the pilot stocks. As expected, short selling activities increased significantly for the pilot stocks relative to other stocks during the suspension period (e.g., Diether et al. [2009], Grullon et al. [2012], Angelis et al. [2013]). Prior research argues that short selling facilitates incorporation of unfavorable information into share prices and that short-sale constraints make it harder for prices to reflect negative information (e.g., Miller [1977], Hong and Stein [2003]). Consistent with this view, Grullon et al. [2012] and Angelis et al. [2013] find that the pilot stocks' share prices become more sensitive to negative earnings surprises, but not to positive earnings surprises, during the suspension period. Our study shows a similar pattern for management earnings forecasts.

Building on these arguments and facts, we predict that managers, in response to the shock of short selling pressure, reduce the precision of bad news forecasts to minimize their influence on share prices. Kim and Verrecchia [1991] show analytically that stock prices react more strongly to more precise information. Consistent with the Kim and Verrecchia [1991] theory, Baginski et al. [1993] find that point forecasts are associated with stronger market reactions than other, less precise, types of forecasts. Thus, it appears to be intuitive that managers, in response to exogenously increased price sensitivity to bad news, reduce bad news forecast precision to maximize stock prices. One may argue that managers can respond to this shock simply by withholding bad news or providing upwardly biased forecasts. However, we argue that these alternative strategies are very costly because of litigation or reputation concerns (e.g., Skinner [1994], Hirst et al. [2008], Cheng et al. [2013]). 
Prediction 1: Pilot firms reduce their bad news forecast precision relative to control firms during the Reg SHO implementation period.

Our investigation is related to two studies. Skinner [1994] finds that bad news forecasts are less precise and Choi et al. [2010] show that the more negative the bad news, the lower the precision. Our study differs from Skinner [1994] and Choi et al. [2010] by examining the effect of an exogenous change in price sensitivity to bad news instead of the effect of bad news per se on forecast precision. Moreover, our setting of a natural experiment can provide important causal implications.

One substantial stream of management forecast research argues that managers may issue "bad news" guidance to walk down overly optimistic analysts and to avoid negative earnings surprises during earnings announcements (Cotter et al. [2006], Kross et al. [2011]). It is possible that more precise forecasts are more effective in walking down optimistic analysts, thereby avoiding negative earnings surprises and future price declines. This study, however, does not focus on the particular type of guidance that is motivated by overly optimistic analyst forecasts. Instead, we examine the general case in which managers are endowed with real information that needs to be disclosed (e.g., because of litigation concerns or pressure from analysts). Therefore, our hypothesis is not in direct competition with the arguments and findings of the "walk-down" research.

\section{Data and Variable Measurement}

\subsection{DATA}

We obtain a list of the Russell 3000 Index member firms from Russell Investments. Following Diether et al. [2009], we use the 2004 and 2005 versions of the Russell 3000 Index to 
construct our initial sample. Specifically, we retain firms that were in the Russell 3000 Index in both 2004 and 2005. We then merge this list with the list of pilot securities announced by the SEC on July 28, 2004, resulting in 864 unique pilot firms and 1,740 unique control firms. ${ }^{7}$ Finally, we obtain necessary data for the pilot and control firms from Thomson First Call's Company Issued Guidance (CIG) Database (management forecast data), S\&P Compustat (financial data), Center for Research in Securities Prices (stock price and volume data), I/B/E/S (analyst estimates data), and Thomson's CDA/Spectrum Database (institutional holdings data). Our sample period covers eight quarters before and eight quarters after the implementation date of Reg SHO (May 2, 2005). ${ }^{8}$ We include quarterly point and range earnings forecasts issued during a fiscal quarter to predict earnings per share for the current quarter. ${ }^{9}$ This procedure leads to a final sample of 3,130 quarterly point and range forecasts for 346 unique pilot firms and 6,175 quarterly point and range forecasts for 711 unique control firms with non-missing control variables. $^{10}$

Chuk et al. [2013] find that the CIG database tends to cover press releases that contain an EPS forecast with a specific dollar amount and press releases that convey bad news. In addition, coverage of CIG is less complete before 1997. These coverage biases of CIG are unlikely to be a significant concern, because our research focuses on quantitative EPS forecasts containing bad earnings news. Our sample period is also much more recent than 1997. Chuk et al. [2013] also

\footnotetext{
${ }^{7}$ The pilot stocks consist of 50\% NYSE-listed securities, 2.2\% AMEX-listed securities, and 47.8\% NASDAQ NNM securities. See http://www.sec.gov/rules/other/34-50104.htm.

${ }^{8}$ The event quarter 0 is included in the post-Reg SHO window. However, inferences remain unchanged if we exclude the event quarter and use the alternative windows: $[-8,-1]$ and $[+1,+8]$ (see the online appendix for robustness tests).

${ }^{9}$ Point and range forecasts represent $93.2 \%$ of all quarterly earnings forecasts in the First Call Database during the period 2002 to 2007.

${ }^{10}$ We focus on quarterly earnings forecasts because prior research finds that quarterly management earnings forecasts attract the greatest attention and have the greatest impact on market prices (e.g., Baginski et al. [1993], Pownall et al. [1993]). However, all the results hold if we also include annual earnings forecasts.
} 
find that CIG tends to cover larger firms with higher analyst following and institutional ownership. Our subsequent cross-sectional tests suggest that the main results of our study are more pronounced for smaller firms and firms with less analyst coverage. Therefore, coverage of CIG biases against finding significant results for our study. That is, the main results would likely be even stronger if the missing firms (smaller firms with low analyst following) were included in our sample.

\subsection{MEASURING MANAGEMENT FORECAST PRECISION}

Following Johnson et al. [2001] and Cheng et al. [2013], we measure forecast precision (PRECISION) as the negative of management forecast width. For range forecasts, forecast width is the difference between the upper- and the lower-end estimates, scaled by beginning-of-quarter stock price. For point forecasts, we assign a zero forecast width. Thus, higher values of PRECISION indicate more precise management forecasts.

\subsection{MEASURING MANAGEMENT FORECAST NEWS}

We use two methods to estimate management forecast news. First, under the traditional approach, management forecast news or forecast surprise (MFSURP) is computed as the difference between the point estimate (or the mid-point estimate of the range forecast) and the consensus analyst forecast, scaled by beginning-of-quarter share price. The consensus analyst forecast is the median of outstanding analyst forecasts (collected from the IBES Summary History files) at the time of the management forecast. ${ }^{11}$ We classify each management forecast as

\footnotetext{
${ }^{11}$ Inferences are identical if we use the IBES detailed forecast file to construct consensus forecasts (see the online appendix for robustness tests).
} 
conveying good news, neutral news, or bad news according to the sign of the forecast news. ${ }^{12}$ In our main regression analysis, by research design, we exclude neutral forecasts.

Rogers and Van Buskirk [2013] show that the traditional measure of forecast news has an inherent measurement error problem for bundled forecasts. These authors develop an alternative method for calculating forecast news ("the RV measure”) for bundled forecasts and suggest researchers use this new measure in concert with the traditional measure to triangulate empirical results. In our sample, bundled forecasts represent $68.7 \%$ and $75.8 \%$ of all forecasts issued by the pilot firms during the pre- and post-Reg SHO windows, respectively. For the control firms, bundled forecasts are $67.3 \%$ and $75.8 \%$ of all forecasts issued during the pre- and post-Reg SHO windows, respectively. Given the significant presence of bundled forecasts in our sample, we also use the RV measure in addition to the traditional forecast news measure for all tests involving management forecast news.

The percentages of good news, bad news, and neutral forecasts for pilot firms based on the traditional news measure (RV measure) are 30.0\% (44.7\%), 56.8\% (52.3\%), and 12.2\% (3.0\%), respectively. For control firms, the percentages of good news, bad news, and neutral forecasts based on the traditional news measure (the RV measure) are 32.4\% (45.7\%), 55.1\% (50.8\%), and 12.5\% (3.5\%), respectively. In addition, we find that 992 (222) bad (good) news forecasts under the traditional approach are re-classified as good (bad) news based on the RV measure.

\subsection{CONTROL VARIABLES}

Following the literature on management forecast precision, we include a vector of firm

\footnotetext{
12 Inferences are unchanged if we define forecast news as neutral when the magnitude of forecast news is very small (for instance, the absolute forecast news being in the bottom quintile of the sample distribution).
} 
and forecast characteristics that can affect a firm's management forecast precision. In our forecast precision model, we include firm size (logarithm of market capitalization at the beginning of the quarter), book-to-market ratio (book value divided by market value at the beginning of the quarter), a loss indicator (one if the firm reports negative actual earnings in the quarter), annual stock return (cumulated daily returns over the twelve-month period before the current quarter), daily return volatility (volatility of daily returns over the twelve-month period before the current quarter), litigation risk (litigation risk measure of Kim and Skinner [2012]), analyst following (number of analysts following the firm during the current quarter), institutional ownership (percentage of shares held by institutional investors during the current quarter), management forecast horizon (number of calendar days between the management forecast release date and the fiscal quarter end date of the quarterly forecast), management forecast error (absolute difference between forecast estimate and actual earnings, scaled by pre-release share price), and absolute forecast surprise (absolute management forecast news, where forecast news is defined in Section 3.3). The appendix provides detailed definitions for all variables used in our regression analysis.

\subsection{DESCRIPTIVE STATISTICS}

Table 1 presents descriptive statistics for the main variables measured before (panel A) and after (panel B) adoption of Reg SHO. As discussed, the SEC picked the pilot firms randomly from the Russell 3000 Index. Therefore, we expect no significant differences in firm characteristics between pilot firms and control firms. However, after requiring non-missing management forecasts and other relevant data for our tests, there appears to be several differences between our pilot firm and control firm samples. For example, in panel A, pilot firms are on average slightly larger than control firms prior to Reg SHO. There are also some minor 
differences in litigation risk, analyst following, institutional ownership, and forecast surprise. ${ }^{13}$ Overall, pilot firms and control firms are very similar. Nonetheless, we control for these firm characteristics in our difference-in-differences regressions. In panel B, during the post-Reg SHO period, pilot firms have lower management forecast precision (mean and median), lower absolute forecast error (mean), and lower absolute forecast surprise (mean).

\section{Main Empirical Analysis}

\subsection{REG SHO AND PRICE SENSITIVITY TO FORECAST NEWS}

We first examine the impact of Reg SHO on stock price sensitivity to management forecast news. The removal of short-sale restrictions increases short selling activity, which imposes greater downward pressure on stocks with bad news. Consistent with this argument, several studies document that Reg SHO increases short selling activity and stock price sensitivity to negative earnings surprises (e.g., Diether et al. [2009], Grullon et al. [2012]). Our purpose here is to confirm whether the same effect exists for management earnings forecasts. Specifically, we estimate the following regression model: ${ }^{14}$

$$
C A R[-2,+2]=\alpha+\beta(M F S U R P)+\gamma(P O S T)+\delta(P O S T \times M F S U R P)+\theta(X)+\varepsilon,
$$

where $C A R[-2,+2]$ is the five-day cumulative market-adjusted abnormal return around the management forecast release date; ${ }^{15}$ MFSURP is the magnitude of management forecast news as defined in Section 3; POST is an indicator variable that takes the value of one if the current

\footnotetext{
${ }^{13}$ Table OA1 of the online appendix presents descriptive statistics for the full sample of pilot and control firms (regardless of whether they issue management forecasts). Overall, we find that the statistical differences in firm characteristics between pilot and control firms are consistent across the full sample and the reduced sample with management forecast data.

${ }^{14}$ Inferences are the same if we include concurrent earnings surprise as an additional control variable when the management forecast is issued around an earnings announcement.

${ }^{15}$ Inferences are identical when we use a three-day event window.
} 
quarter is within the eight-quarter period after the adoption date of Reg SHO, and zero if the current quarter is within the eight-quarter period preceding the adoption date; $P O S T \times M F S U R P$ is the interaction term between POST and MFSURP, the coefficient of which measures the change in price sensitivity to forecast news around adoption of Reg SHO; and vector $X$ represents a set of control variables, including size and market-to-book, and their interactions with POST and MFSURP. Standard errors are clustered at the firm level throughout the paper. We estimate Eq. (1) separately for four groups of firms: pilot firms with negative forecast news, control firms with negative forecast news, pilot firms with positive forecast news, and control firms with positive forecast news.

Table 2 presents the regression results for estimating Eq. (1). Panel A of Table 2 reports the results for bad news forecasts. Columns (1) and (2) present the traditional forecast news results for pilot firms and control firms, respectively. Columns (3) and (4) present the RV measure-based results. In addition to forecast news, in columns (3) and (4), we also adjust forecast announcement returns (i.e., $C A R[-2,+2]$ ) for bundled forecasts using a method similar to that in Rogers and Van Buskirk [2013]. ${ }^{16}$ In column (1), the coefficient of POST $\times$ MFSURP is positive and significant at the $5 \%$ level, suggesting that price sensitivity to bad news forecasts issued by pilot firms increases significantly after implementation of Reg SHO. ${ }^{17}$ In contrast, column (2) shows that price sensitivity to bad news forecasts does not change significantly for the control group. The coefficient of $P O S T \times M F S U R P$ for the pilot firm sample is significantly different from that for the control sample. After adjustment of forecast news and forecast announcement returns using the method of Rogers and Van Buskirk [2013], the coefficient of

\footnotetext{
${ }^{16}$ See the appendix for more details.

${ }^{17}$ In columns (1) and (3), the coefficient of MFSURP is negative. Note, however, that the coefficient of the main effect is not very meaningful in regressions with interaction terms, because it represents the loading on the main effect when all control variables take the value of zero. In regressions without control variables, the coefficient of MFSURP is positive and significant.
} 
$P O S T \times M F S U R P$ for the pilot firms becomes even larger and is significant at the $1 \%$ level. Surprisingly, the coefficient of $P O S T \times M F S U R P$ for the control firms becomes significant, albeit with a small magnitude. More importantly, the coefficient of $P O S T \times M F S U R P$ for the pilot firms is significantly larger than that for the control firms.

Panel B of Table 2 reports the results from estimating Eq. (1) for good news forecasts. The coefficient of $P O S T \times M F S U R P$ is generally insignificant for both the pilot and control firms, irrespective of how forecast news or forecast announcement returns are calculated. ${ }^{18}$ Overall, the results in Table 2 show that Reg SHO increases price sensitivity to bad news forecasts of pilot firms and it has no meaningful (or much weaker) effects on bad news forecasts of the control firms or good news forecasts of both the pilot and control firms. Thus, we argue that Reg SHO represents an exogenous shock to stock price sensitivity to bad news for the pilot firms, since we have no reason to believe that the pilot firms have any influence over the SEC's random selection process.

\subsection{REG SHO AND MANAGEMENT FORECAST LIKELIHOOD}

Before turning to our main test, we now examine whether Reg SHO impacts the likelihood of management forecast issuance. Prior research argues that managers have less discretion over the decision of whether to issue a forecast, because of litigation or reputation concerns. In a survey of the management forecast literature, Hirst et al. (2008) argue that the decision to issue a forecast is influenced by pre-existing conditions or antecedents, and these

\footnotetext{
${ }^{18}$ The coefficient of MFSURP is insignificant for our sample of good news forecasts. There are two potential interpretations. First, the magnitude of good news could be less relevant in the market because good news forecasts are perceived to be less credible (e.g., Hutton et al. [2003]). Second, the insignificant results can be partially caused by inaccurate measurement of forecast news or forecast announcement returns for bundled forecasts. In fact, under the RV method, the coefficient of MFSURP is significantly positive for the good news forecast sample if we do not include control variables and their interactions with MFSURP in the regression.
} 
antecedents are not easily changed in the short term. However, in our setting, there remains a possibility that some managers respond to increased short selling pressure by forgoing bad news forecasts instead of reducing the precision of these forecasts. If this is the case for a significant number of firms, our main tests may suffer from a typical self-selection bias, because we are able to observe only the precision of forecasts actually issued. ${ }^{19}$ In this section, we check whether the self-selection concern is a real-world problem by examining the effect of Reg SHO on forecast likelihood. Toward this end, we track the forecast incidences of all the pilot and control firms over our sample period and estimate the following difference-in-differences logistic regression: ${ }^{20}$

$$
\operatorname{Pr}(\text { ISSUE })=\alpha+\beta(P I L O T)+\gamma(P O S T)+\delta(P O S T \times P I L O T)+\theta(X)+\varepsilon,
$$

where ISSUE takes the value of one for firm-quarters with at least one management forecast, zero otherwise; ${ }^{21}$ PILOT is an indicator variable that takes the value of one for all quarterly observations of pilot firms, zero for control firms; POST is as defined in Eq. (1); POST $\times$ PILOT is the interaction term between POST and PILOT; the coefficient of POST $\times$ PILOT, $\delta$, measures the difference in changes of forecast likelihood around Reg SHO between pilot firms and control firms; and vector $X$ represents the set of control variables as defined in Section 3. We also include firm fixed effects and quarter indicators to control for time-invariant firm characteristics and time-specific effects, respectively.

Table 3, column (1), presents the results from estimating Eq. (2). The indicator variable, PILOT, is subsumed by firm fixed effects. The coefficient of POST is negative and significant,

\footnotetext{
${ }^{19}$ In untabulated robustness tests, we address this problem using the Heckman two-stage procedure; the conclusions are unchanged. However, the Heckman approach is unlikely to be effective since we cannot find a truly exogenous variable that affects forecast precision via only its effect on forecast likelihood.

${ }^{20}$ In conducting this test, we keep all pilot and control firms that are covered by First Call's Actuals data set.

${ }^{21}$ Inferences are the same if we use the number of forecasts as the dependent variable. See Table OA2 of the online appendix.
} 
indicating a decreasing trend of management forecast likelihood, after controlling for timevariant and time-invariant firm characteristics as well as time-specific effects. ${ }^{22}$ The coefficient of $P O S T \times P I L O T$ is insignificant, suggesting that there is no significant difference in the changes of forecast likelihood around Reg SHO between the pilot and the control firms. Columns (2) and (3) present the results of re-estimating Eq. (2) by replacing the dependent variable with good news forecast likelihood and bad news forecast likelihood, respectively, where forecast news is calculated using the traditional approach. The coefficient of $P O S T \times P I L O T$ is insignificant in both good news and bad news forecast regressions. Columns (4) and (5) show that the coefficient of POST $\times$ PILOT continues to be insignificant in both good news and bad news forecast regressions when we use the RV measure to classify forecast news. Overall, the results presented in Table 3 show no evidence that pilot firms change the incidence of their management forecasts relative to control firms. More importantly, columns (3) and (5) of Table 3 show that neither pilot firms nor control firms change the incidence of bad news forecasts around Reg SHO, regardless of which measure of forecast news is used.

In the online appendix, we further examine whether there is a notable subset of firms that change their propensity to issue bad news forecasts. To do this, we introduce into Eq. (2) interaction terms between POST $\times$ PILOT and several meaningful firm characteristics, such as firm size, analyst coverage, and institutional ownership. We find that the coefficients of all of the triple interaction terms are insignificant. ${ }^{23}$ The results in this section can be partially explained by managers' lack of control or discretion over forecast issuance in the short term, particularly for bad news issuance. Alternatively, managers may hold a belief that stopping the issuance of

\footnotetext{
${ }^{22}$ Note that the inclusion of quarter fixed effects can make the coefficient of POST less useful in detecting the absolute trend (for control firms). The conclusions remain unchanged if we exclude quarter fixed effects.

${ }^{23}$ See Tables OA3 to OA6 of the online appendix for more details regarding tests on the likelihood or frequency of management forecasts under various model specifications.
} 
bad news forecasts can be interpreted as even worse news by investors. In any event, the results in this section partially alleviate concern over self-selection. It appears that the choice over whether to issue management forecasts is not affected by Reg SHO. ${ }^{24}$

\subsection{REG SHO AND MANAGEMENT FORECAST PRECISION}

In this section, we examine the impact of Reg SHO on management forecast precision. Specifically, we estimate the following difference-in-differences regression:

$$
\text { PRECISION }=\alpha+\beta(\text { PILOT })+\gamma(\text { POST })+\delta(\text { POST } \times \text { PILOT })+\theta(X)+\varepsilon,
$$

where PRECISION is management forecast precision as defined in Section 3; PILOT, POST, and $P O S T \times P I L O T$ are as defined in Eq. (2); and vector $X$ represents the set of control variables as defined in Section 3. The coefficient of POST $\times$ PILOT, $\delta$, measures the difference in changes of forecast precision around Reg SHO between pilot firms and control firms Alternatively, it can be interpreted as changes in relative forecast precision (relative to the control group) for pilot firms around Reg SHO. A negative value of $\delta$ implies that Reg SHO causes a reduction in forecast precision of pilot firms relative to control firms.

Prior research argues that investors in larger firms or firms with higher growth opportunities demand more precise forecasts (e.g., Cheng et al. [2013]). We include firm size and book-to-market ratio to capture the demand effect. Prior research finds that firms with declining earnings or bad performance are more likely to issue less precise forecasts (e.g., Bamber and Cheon [1998]). We use a loss indicator and annual stock return to capture the

\footnotetext{
${ }^{24}$ As a robustness check, we remove the pilot and control firms that changed their forecast issuance patterns around Reg SHO and the conclusions are unchanged. Moreover, in Section 4.4, we use an alternative setting without the selection problem to re-examine our central thesis that managers respond to Reg SHO by obfuscating bad news disclosures.
} 
performance effect. Managers are more likely to issue less precise forecasts when facing more uncertainty. We use stock return volatility as the proxy for uncertainty (e.g., Rogers and Stocken [2005]). We also control for litigation risk because prior research argues that higher litigation risk is associated with lower management forecast precision (e.g., Skinner [1994]). We include analyst coverage and institutional ownership to capture the demand for precise forecasts. We also include three forecast characteristics to further capture managers' uncertainty: forecast horizon, absolute forecast error, and absolute forecast surprise (e.g., Baginski and Hassell [1997], Choi et al. [2010], Cheng et al. [2013]). ${ }^{25}$ Finally, we include firm fixed effects and quarter fixed effects in all regression specifications.

Table 4 reports results from estimating Eq. (3). Columns (1) and (2) report results for the traditional measure of forecast news, and columns (3) and (4) report results for the RV measure of forecast news. Consistent with our prediction, columns (1) and (3) show that the coefficient of $P O S T \times P I L O T$ is negative and significant for bad news forecasts, regardless of which measure of forecast news is used. For example, in column (3), where the RV measure is used to classify forecast news (as well as the calculation of control variables involving forecast news), the coefficient of POST $\times P I L O T$ is -0.031 , significant at the $5 \%$ level. The magnitude of the coefficient indicates that, after removal of short-sale constraints for the pilot firms, bad news forecast precision of pilot firms decreases by 0.031 units more than control firms, which represents $17 \%$ (27\%) of mean (median) forecast precision. Thus, it appears that the impact of Reg SHO on bad news forecast precision is both statistically and economically significant. Columns (2) and (4) of Table 4 report results from estimating Eq. (3) for the good news forecast sample. The coefficient of POST $\times P I L O T$ is insignificant in both columns, suggesting that Reg

\footnotetext{
${ }^{25}$ Forecast surprise is one of the two measures of forecast news defined in Section 3.
} 
SHO has no effect on the precision of good news forecasts.

We also examine the time-series dynamics of the impact of Reg SHO on management forecast precision. To do this, we replace the indicator variable POST in Eq. (3) with eight indicator variables representing the individual quarters during the treatment period and reestimate the main regression. Table OA7 of the online appendix presents the results. We find that pilot firms begin reducing bad news forecast precision from the second quarter following implementation of Reg SHO. The (statistically) significant reductions in bad news forecast precision, however, are concentrated in the latter half of the treatment period (quarters $[+4,+7]$ ). In addition, Table OA8 shows that a pilot firm reduces its bad news forecast precision to a greater extent during the second half of the treatment period if its industry peers reduce their forecast precision more during the first half of the treatment period. Finally, we find that smaller firms and firms with low analyst following begin reducing their bad news forecast precision significantly during the first half of the treatment period.

Overall, the results support our central prediction that there is a causal effect of short selling pressure and consequent price sensitivity to bad news on the precision of bad news forecasts. More generally, these results indicate that the stock market has a causal effect on managers' strategic disclosure choices.

\subsection{REG SHO AND ANNUAL REPORT READABILITY}

The forecast likelihood results of Section 4.2 suggest that self-selection is unlikely to be a severe problem for our management forecast precision tests. To further alleviate self-selection concerns, in this section, we use an alternative construct to examine the central thesis that managers respond to the positive shock to price sensitivity to bad news by obfuscating disclosure 
of negative information. In addition, we investigate whether the findings on forecast precision are generalizable to other disclosure settings. The Bloomfield [2002] incomplete revelation hypothesis (IRH) predicts that managers can reduce market response to bad news by making bad news more costly to analyze (Grossman and Stiglitz [1980]). Consistent with IRH, Li [2008] shows that the annual reports of firms with negative earnings are harder to read. In a more recent paper, Bushee et al. [2014] provide corroborating evidence that managerial linguistic complexity in firm disclosures reflects obfuscation rather than information. Based on theory and evidence, we predict that managers of pilot firms reduce the readability of their bad news $10-\mathrm{K}$ reports around implementation of Reg SHO. Specifically, we estimate the following difference-indifferences regression:

$$
\operatorname{lnFOG}=\alpha+\beta(P I L O T)+\gamma(P O S T)+\delta(P O S T \times P I L O T)+\theta(X)+\varepsilon,
$$

where FOG is the Gunning Fog Index of 10-K filings obtained from Li [2008]. This measure, developed in the computational linguistics literature, captures the written complexity of a document as a function of the number of syllables per word and the number of words per sentence. ${ }^{26}$ Higher values of FOG indicate less readable annual reports. InFOG is the logarithm of one plus FOG. PILOT is an indicator variable that takes the value of one if the $10-\mathrm{K}$ report belongs to a pilot firm, zero otherwise. POST is an indicator variable that takes the value of one if the year is within the two-year period following adoption of Reg SHO and zero if the current year is within the two-year period prior to adoption. POST $\times$ PILOT is the interaction term between POST and PILOT. The coefficient of POST $\times$ PILOT, $\delta$, measures the difference in changes in annual report readability around Reg SHO between the pilot and control firms. A

\footnotetext{
${ }^{26}$ Please refer to $\mathrm{Li}$ [2008] for a more detailed discussion on the construction of the Fog Index. We thank Feng Li for sharing the annual Fog Index data on his website.
} 
positive value of $\delta$ implies that Reg SHO causes a greater reduction in annual report readability of pilot firms relative to control firms.

Vector $X$ represents the set of control variables taken from Li [2008], including earnings performance $(E A R N)$, firm size (SIZE), market-to-book ratio (MTB), firm age (AGE), special items $(S I)$, return and earnings volatility (RETVOL, EARNVOL), the number of business segments (NBSEG), financial complexity (NITEMS), and two special event indicators (SEO, $M A) .{ }^{27} \mathrm{Li}$ [2008] argues that firms with lower earnings, a larger size, higher growth, a younger age, lower special items, more volatile business environments, more complex operations and financial situations, and more firm events such as M\&A and SEO, tend to have more complex annual reports. Similar to management forecast tests, we also include firm and year fixed effects in the regression model.

We estimate Eq. (4) separately for firms with negative earnings news and positive earnings news. Because the annual earnings numbers are disclosed before the $10-\mathrm{K}$ filing dates, we are not able to estimate earnings news in the annual reports. We classify an annual report as containing bad (good) news if the firm's annual ROA is lower (higher) than the industry median ROA. ${ }^{28}$ Columns (1) and (2) of Table 5 present the results. Consistent with our prediction, column (1) shows that the coefficient of $P O S T \times P I L O T$ is positive and significant for the sample of firms with bad earnings news. The magnitude of the coefficient indicates that pilot firms with lower earnings (relative to industry-average earnings) reduce their annual report readability by

\footnotetext{
${ }^{27} \mathrm{Li}$ [2008] also includes the state of incorporation as a control variable. We do not need this control variable because of the inclusion of firm fixed effects.

${ }^{28} \mathrm{Li}$ [2008] defines good/bad earnings news (or high vs. low earnings) using raw net income (i.e., a loss indicator for bad earnings news). We argue that our benchmarking of profit relative to industry performance is more powerful. In robustness tests, we also use zero earnings (as in Li [2008]), analysts' annual earnings forecasts, or last year's earnings as benchmarks to define good/bad earnings news. We also use market reaction around 10-K filings to define good/bad news. The results are qualitatively unchanged (albeit weaker).
} 
3.2\% around implementation of Reg SHO, relative to control firms. On the other hand, column (2) shows that the coefficient of $P O S T \times P I L O T$ is insignificant for the sample of firms with good earnings news. One may argue that a $3.2 \%$ reduction in readability is not very significant economically. However, we note that the magnitude in our tests is in line with the finding of $\mathrm{Li}$ [2008], which shows that annual report readability of loss firms is on average $0.9 \%$ lower than that of profit firms. ${ }^{29}$ Loughran and McDonald [2014] argue that the file size of 10-K reports can be an alternative (inverse) measure of annual report readability. Thus, we also estimate Eq. (4) after replacing FOG with the 10-K file size (FILESIZE). Consistent with the results using FOG, column (3) of Table 5 shows that pilot firms with poor earnings news increase the file sizes of their $10-\mathrm{K}$ reports by $13.3 \%$ relative to control firms around Reg SHO. On the other hand, column (4) shows that there are no significant changes in the size of $10-\mathrm{K}$ reports with positive earnings news for pilot firms. ${ }^{30}$

Overall, the results discussed in this section support the conjecture that managers, in response to the positive shock to short selling pressure, reduce the readability of bad news annual reports, which is inherently consistent with our earlier tests on management forecast precision. That is, managers respond to the positive shock to price sensitivity to bad news by obfuscating disclosures of negative information. An advantage of the annual report disclosure setting is that we are less concerned with the self-selection problem associated with management earnings forecasts tests. Moreover, Lehavy et al. [2011] argue that annual report readability is a more comprehensive measure of disclosure characteristics than other disclosure measures that focus on one single financial statement item. At the same time, however, given the diverse and rich

\footnotetext{
29 The magnitude is estimated from Table 1 and Table 3 of Li [2008].

${ }^{30}$ Interestingly, we find that pilot firms that reduce the readability of their annual reports are also more likely to reduce the precision of their management forecasts (see Table OA9 of the online appendix).
} 
information contained in annual reports, classifying news of annual reports based solely on reported earnings is likely to introduce significant measurement errors. In addition, there is an ongoing debate over the appropriate measurement of financial disclosure readability. Therefore, our analysis on annual report readability is explorative in nature, and we leave an in-depth examination of changes in financial report readability around Reg SHO to future research.

\subsection{OTHER CHARACTERISTICS OF MANAGEMENT FORECASTS}

The main objective of our research is to examine whether managers strategically respond to increased short selling pressure by decreasing the precision of bad news disclosures. This pursuit is partially motivated by the observation that managers tend to obfuscate disclosure of bad news to maintain the current level of stock prices (e.g., Bloomfield [2002]). One may contend that manipulating the sign and magnitude of forecast news could achieve the same end. We argue, however, that managers have less freedom in manipulating the amount of forecast news, due to litigation and reputation concerns. Moreover, the amount of forecast news is largely endowed by the economic reality of the firm, over which managers have less control at the point of forecast issuance. To capture the "discretionary portion" of forecast news, we need to control for the true amount of news observed by managers, which is very difficult. Nonetheless, it is interesting to see whether the amount of forecast news or bias changes for pilot firms relative to control firms around Reg SHO. Using management forecast surprise as a measure of the amount of forecast news, we estimate a difference-in-differences regression similar to Eq. (3) and report the results in columns (1) and (2) of Table 6. The coefficient of POST $\times$ PILOT is insignificant for both the traditional forecast news measure and the RV measure. Column (3) of Table 6 reports the results of estimating the difference-in-differences regression using management forecast bias as the dependent variable. The coefficient of POST $\times P I L O T$ is again insignificant. Overall, there 
is no evidence that managers respond to Reg SHO by manipulating the sign and magnitude of forecast news.

Prior research suggests that managers can learn from stock market prices in making their decisions (e.g., Chen et al. [2007]). In fact, Zuo [2013] provides evidence that managers learn from stock prices when making forward-looking disclosures. Increased short selling activity can increase the informativeness of stock prices, especially with regard to negative information. Learning from more informative prices, managers can then make more precise or accurate bad news forecasts. Thus, there is a reason to believe that short selling pressure and consequent price informativeness have a positive effect on management forecast precision. While this argument represents an interesting tension in our investigation, it is not supported by our main empirical results. To further examine the potential learning (from price) effect, we examine the effect of Reg SHO on management forecast accuracy (proxied by absolute forecast error). Column (4) of Table 6 presents the results. The coefficient of $P O S T \times P I L O T$ is negative but not significant at conventional levels, suggesting that management forecast errors are somewhat reduced but that the reduction in errors does not achieve statistical significance. Overall, the "learning from stock prices” effect is not well supported by our empirical results.

\subsection{ADDITIONAL ANALYSIS AND ROBUSTNESS CHECKS}

Angelis et al. [2013] find that Reg SHO increases use of stock options in managerial compensation packages. It is possible that Reg SHO impacts management forecast precision through its effects on compensation structures. We argue that our results are unlikely to be driven solely by the compensation structure effect. Specifically, if stock options indeed have an effect on forecast precision, they should affect both good news forecasts and bad news forecasts. 
Nonetheless, to ensure that our results are not driven by changes in compensation structures, we re-estimate Eq. (3) by including additional variables that capture the proportion of stock options in executive compensation (untabulated). Our inferences continue to hold. Grullon et al. [2012] find that Reg SHO reduces the levels of investment and equity financing in pilot firms. Similarly, if investment and financing levels have an impact on forecast precision, they should affect both good news and bad news forecasts. As expected, our conclusions remain unchanged when we reestimate Eq. (3) by including additional control variables, such as R\&D and capital expenditures, debt issuance, and equity issuance.

One may argue that there is a time trend in management forecast precision, and that this trend, for unknown reasons, differs between pilot and control firms. We argue that this is unlikely to be the case, because the SEC selected the pilot firms using a random sampling process. Nevertheless, we conduct a placebo test to further ensure the validity of our results. Specifically, we define the placebo event date as May 2, 2002 (i.e., three years before the real event date). Then, we collect data for the pilot and control firms for the 16-quarter period centered at the placebo event date. Table OA10 of the online appendix presents the placebo test results. We find no evidence that pilot firms reduce their bad news forecast precision relative to control firms around this placebo event date.

In July 2007, the SEC eliminated the uptick rule for all firms. As a result, short-sale constraints for control firms should decrease to a similar level as those for the pilot firms after July 2007. We now examine whether control firms reduce their forecast precision around the ending of the SEC experiment. To do this, we replace the variable POST (i.e., the event date variable) in Eq. (3) by POST_END, which is an indicator variable that takes the value of one if the current quarter is located within the four-quarter period after July 2007, zero if the current 
quarter is located within the four-quarter period before July 2007. The definitions for PILOT and other variables are the same as in Eq. (3). ${ }^{3132}$

Table 7 reports the results. The coefficient of POST_END is negative and significant, suggesting that control firms react to increased short selling pressure around the ending of the experiment by reducing their bad news forecast precision. The magnitude of the reduction, however, is much smaller than that of the reduction in forecast precision of pilot firms during the experiment. In fact, even after July 2007, the forecast precision of pilot firms remains significantly lower than that of control firms. ${ }^{33}$ Therefore, it appears that control firms underreact to the removal of short sale constraints (around July 2007) relative to pilot firms (around May 2005). One potential reason for this is that the post-experiment period coincides with the beginning of the financial crisis. It is possible that firms do not have the same incentives to maintain the level of stock prices during (or immediately before) a market crash (e.g., Jensen [2005]). ${ }^{34}$ Nonetheless, we caution against over-interpretation of our results, since the treatment firms and control firms in this post-experiment event are not randomly selected. The fact that the two groups of firms receive different treatments around implementation of Reg SHO (i.e., the first event) imposes systematic differences on them before the second event. ${ }^{35}$

In an alternative difference-in-differences design, we first calculate the average forecast precision (and control variables) for each pilot or control firm over the eight quarters before and

\footnotetext{
${ }^{31}$ In this regression, we exclude time fixed effects to make it easier to interpret the coefficient on POST (which is now the variable of interest).

${ }^{32}$ Essentially, around the "experiment expiration" event, the original control firms are the treated firms (whose short-sale constraints are reduced) and the pilot firms are the new control firms (whose short-sale constraints remain unchanged).

${ }^{33}$ As expected, pilot firms do not change their bad news forecast precision significantly relative to control firms around the ending of the experiment. However, although there is no change in short-sale constraints for the pilot firms at this time point, we still observe some additional drifts in pilot firms' reaction to Reg SHO.

${ }^{34}$ It is also possible that control firms exhibit a delayed reaction when adjusting their forecast precision. However, inferences are identical if we expand the post-experiment window to eight quarters or longer.

35 This is why the "placebo test" should be conducted with pre-treatment data.
} 
the eight quarters after Reg SHO. Next, we calculate the change in forecast precision (and control variables) around Reg SHO for each firm. We then estimate a regression of the change in bad news forecast precision on the pilot firm indicator (PILOT) and changes in control variables (with one observation for each firm). The results in Table OA11 of the online appendix show that the coefficient of PILOT is negative and significant, consistent with the results in our main tests.

Our study focuses on point and range forecasts, because calculation and classification of forecast news is more straightforward for such forecasts. Prior literature typically argues that open-ended and qualitative forecasts are less precise than point and range forecasts (e.g., Baginski and Hassell [1997], Bamber and Cheon [1998], Rogers and Van Buskirk [2009]). Table OA12 in the online appendix examines whether pilot firms reduce the number of point and range bad news forecasts relative to control firms; it shows insignificant results. This result may be driven by the extremely small number of open-ended and qualitative forecasts in the sample. ${ }^{36}$

\section{Cross-Sectional Analysis}

In this section, we conduct a series of cross-sectional analyses to further identify the effect of short selling pressure and consequent price behavior on management forecast precision. $^{37}$

\subsection{CEO/CFO EQUITY INCENTIVES}

In our main discussions, we argue that the effect of Reg SHO on bad news management

\footnotetext{
${ }^{36}$ Only $1.67 \%$ of the observations used in Table OA12 are open-ended or qualitative forecasts. Chuk et al. [2013] find that First Call's coverage of qualitative forecasts is incomplete. Thus, the inferences drawn from tests involving First-Call qualitative forecasts are likely to be problematic.

${ }^{37}$ We also conduct similar cross-sectional analyses for the readability measures but find no significant moderating effects.
} 
forecast precision exists because managers have incentives to maintain the current level of stock prices. ${ }^{38}$ To further identify the effect of Reg SHO, we examine whether the impact of Reg SHO on bad news forecast precision is more pronounced when managers' wealth is more strongly tied to stock prices. Toward this end, we introduce interaction terms between measures of CEO/CFO equity incentives and our variables of interest in Eq. (3). Following prior research, we measure CEO/CFO equity incentives as the dollar change in the value of executive option holdings resulting from a $1 \%$ increase in the firm's stock price, scaled by annual cash compensation (e.g., Core and Guay [1999, 2002]). CEO/CFO compensation data are obtained from the Compustat ExecuComp Database. ${ }^{39}$

Table 8 presents the results. Panel A reports the results based on the traditional forecast news measure and panel B presents the results based on the RV news measure. In column (1) of panel A, the coefficient of the triple interaction term involving CEO equity incentives is negative but not significant at conventional levels. In column (2) of panel A, the coefficient of the triple interaction term involving CFO equity incentives is negative and significant at the $5 \%$ level. The moderating effect of CFO equity incentives is twice as large as that of CEO equity incentives, consistent with the argument that CFOs have more influence over corporate disclosure decisions (e.g., Jiang et al. [2010], Kim et al. [2011]). The results shown in panel B are generally consistent with those of panel A. Overall, the results support the conjecture that the effect of Reg SHO on bad news management forecast precision is more pronounced for pilot firms whose managers' wealth is more strongly tied to stock prices. However, readers should take caution in interpreting our evidence as managerial opportunism. It is very likely that equity incentives align

\footnotetext{
${ }^{38}$ Theoretically, we are interested in the effect of price behavior in general, and price sensitivity to bad news in particular, rather than Reg SHO per se. Nevertheless, in this section, we use the term Reg SHO for expositional simplicity.

${ }^{39}$ To facilitate comparisons across models, we use scaled decile ranks of the conditioning variables in our regressions. Inferences are identical if we use raw values.
} 
the interests of managers and investors, and that managers act strategically to maintain the level of stock prices for the welfare of investors (e.g., to retain customer or creditor confidence).

\subsection{EFFECT OF FIRM SIZE AND AGE}

Grullon et al. [2012] find that the impact of Reg SHO on short selling activity and price sensitivity to bad news is larger for smaller pilot firms. Moreover, Hadlock and Pierce [2010] find that smaller or younger firms have higher levels of financial constraints. ${ }^{40}$ As a result, smaller or younger firms may have stronger incentives to maintain the level of stock prices to facilitate financing. Thus, we expect the effect of Reg SHO on management forecast precision to be stronger for smaller or younger pilot firms. To test this conjecture, similar to Section 5.1, we estimate the difference-in-differences regression of Eq. (3) after introducing interaction terms between our variable of interest and firm size or age; we present the results in columns (3) and (4) of Table 8. Overall, we find that the effect of Reg SHO on bad news forecast precision is more pronounced for smaller pilot firms but not for younger firms.

\subsection{FINANCIAL ANALYSTS AND INSTITUTIONAL INVESTORS}

Prior literature argues that financial analysts and institutional investors play an important role in monitoring firms' financial reporting and disclosure decisions. Moreover, financial analysts and institutional investors are major users of management earnings forecasts, and they impose persistent pressure on management to produce more precise earnings forecasts during conferences calls (Ajinkya et al. [2005]). Therefore, we expect the effect of Reg SHO on management forecast precision to be weaker for pilot firms with greater analyst coverage or higher institutional ownership, because managers of these firms have less flexibility in disclosure

\footnotetext{
${ }^{40}$ Hadlock and Pierce [2010] show that firm size and age are much better predictors of financial constraint levels than traditional measures of financial constraints, such as the KZ index.
} 
choices.

To test the above conjecture, we introduce into Eq. (3) interaction terms between our variable of interest and analyst coverage or institutional ownership. Analyst coverage data are collected from I/B/E/S and institutional holdings data are from Thomson's CDA/Spectrum database. Columns (5) and (6) of Table 8 report the results. Consistent with our prediction, the impact of Reg SHO on bad news management forecast precision is more pronounced for pilot firms with smaller analyst coverage, suggesting that managers of these firms have more freedom in strategically choosing earnings forecast precision. In contrast, we find that the moderating effect of institutional ownership is insignificant, albeit with an expected sign.

\subsection{EFFECT OF CHANGES IN ERC}

If managers reduce forecast precision upon observing that their firms' stock prices become more sensitive to negative information, we should expect the effect of Reg SHO on forecast precision to be more pronounced for firms that experience a larger increase in price sensitivity to bad news after Reg SHO. To test this prediction, we should, ideally, estimate firmspecific ERCs using bad news forecasts or negative news quarterly earnings announcements. However, it is difficult to obtain sufficient observations for such firm-specific regressions and this could induce severe survivorship biases. Only firms with a sufficient number of bad news forecasts or negative earnings surprises remain in the sample. Because of this limitation, we use a less ideal method of estimating firm-specific ERCs: using a sample of 20 quarterly earnings observations (including those with both positive and negative news) before and after implementation of Reg SHO. ${ }^{41}$ Then, we calculate the change in the level of ERC for each firm

\footnotetext{
${ }^{41}$ We require a minimum of ten observations for each firm to estimate ERCs.
} 
and use the decile rank of the ERC change (CHGERC) as the conditioning variable. Column (7) of Table 8 reports the results. The coefficient of $C H G E R C \times P O S T \times P I L O T$ is negative and significant in both panels A (traditional news measure) and B (RV news measure), consistent with our prediction.

\section{Conclusion}

This paper provides empirical evidence that the secondary stock market has a causal effect on managerial voluntary disclosure decisions. Using the natural experiment provided by Reg SHO, we find that the removal of short-sale constraints increases stock price sensitivity to negative forecast news. Managers respond to this exogenous shock to stock price behavior by reducing the precision of bad news earnings forecasts. Since more precise forecasts are generally associated with stronger market reactions, our results suggest that managers act strategically to reduce the influence of increased price sensitivity to bad news, thereby maintaining the current level of stock prices. Moreover, we find evidence that managers also reduce the readability of bad news annual reports when facing increased short selling pressure. Finally, we find that the effect of Reg SHO on bad news forecast precision is stronger for firms with higher CFO compensation sensitivity to stock prices, smaller firms, firms with lower analyst coverage, and firms that experience larger increases in stock price sensitivity after Reg SHO.

This research examines an exogenous shock to equilibrium behavior of stock prices and probes how managers react to such a shock. We can then draw causal inferences by observing the process in which management forecast precision reaches a new equilibrium level. One may wonder when the new equilibrium would be reached and what the new equilibrium level would be, or whether the reduction in forecast precision is in fact effective (in maintaining the current 
level of stock prices) or sustainable. We acknowledge that these are useful but very complex questions. Our study focuses on the simpler question of whether the shock to stock price behavior can cause changes in management forecast precision. ${ }^{42}$

Our study represents one of the first efforts to investigate the causal effect of stock price behavior on managers' disclosure choices. Our evidence is consistent with the assumption maintained in the accounting literature that maximizing stock prices is one of the most important factors determining managers' strategic disclosure choices. Managers, in response to increased sensitivity of stock price to bad news, tend to obscure disclosure of negative information. In addition, our empirical results support the general idea of Bond et al. [2012] that secondary market prices have a causal effect on the decisions of corporate managers, and are not simply a sideshow.

\footnotetext{
${ }^{42}$ One possible way to evaluate the effectiveness of the strategy of reducing management forecast precision is to examine whether the stock market reaction to bad news management forecasts is indeed alleviated during the second half of the treatment period, in which managers appear to be more aggressive in obfuscating their bad news forecasts. However, the stock market reaction is jointly determined by managerial disclosure discretion and short selling intensity. Therefore, inferences about the effectiveness of managerial disclosure strategies based on stock market reactions are likely to be inconclusive.
} 


\section{REFERENCES}

AJINKYA, B.; S. BHOJRAJ and P. SENGUPTA. "The association between outside directors, institutional investors and the properties of management earnings forecasts." Journal of Accounting Research 43 (2005): 343-376.

ANGELIS, D. D.; G. GRULLON and S. MICHENAUD. "Downside risk and the design of CEO incentives: Evidence from a natural experiment.” Rice University working paper (2013).

BAGINSKI, S. P.; E. J. CONRAD and J. M. HASSELL. "The effects of management forecast precision on equity pricing and on the assessment of earnings uncertainty.” The Accounting Review 68 (1993): 913-927.

BAGINSKI, S. P. and J. M. HASSELL. "The market interpretation of management earnings forecasts as a predictor of subsequent financial analyst forecast revision." The Accounting Review 65 (1990): 175-190.

BAGINSKI, S. P. and J. M. HASSELL. "Determinants of management forecast precision.” The Accounting Review 72 (1997): 303-312.

BAGINSKI, S. P.; J. M. HASSELL and M. D. KIMBROUGH. "The effect of legal environment on voluntary disclosure: Evidence from management earnings forecasts issued in US and Canadian markets.” The Accounting Review 77 (2002): 25-50.

BAGINSKI, S. P.; J. M. HASSELL and M. M. WIELAND. "Does management earnings forecast form matter?” University of Georgia Working Paper (2007).

BAMBER, L. S. and Y. S. CHEON. "Discretionary management earnings forecast disclosures: Antecedents and outcomes associated with forecast venue and forecast specificity choices." Journal of Accounting Research 36 (1998): 167-190.

BEYER, A.; D. A. COHEN; T. Z. LYS and B. R. WALTHER. "The financial reporting environment: Review of the recent literature.” Journal of Accounting and Economics 50 (2010): 296-343.

BLOOMFIELD, R. J. "The 'incomplete revelation hypothesis' and financial reporting." Accounting Horizons 16 (2002): 233-243.

BOND, P.; A. EDMANS and I. GOLDSTEIN. "The real effects of financial markets.” Annual Review of Financial Economics 4 (2012): 339-360.

BUSHEE, B.; D. IAN and D. J. TAYLOR. "Linguistic complexity in firm disclosures: Obfuscation or information?” Available at SSRN: http://ssrn.com/abstract=2375424 (2014). 
CHEN, Q.; I. GOLDSTEIN and W. JIANG. "Price informativeness and investment sensitivity to stock price.” The Review of Financial Studies 20 (2007): 619-650.

CHENG, Q.; T. LUO and H. YUE. "Managerial incentives and management forecast precision.” The Accounting Review 88 (2013): 1575-1602.

CHOI, J.-H.; L. A. MYERS; Y. ZANG and D. A. ZIEBART. "The roles that forecast surprise and forecast error play in determining management forecast precision.” Accounting Horizons 24 (2010): 165-188.

CHUK, E.; D. MATSUMOTO and G. S. MILLER. "Assessing methods of identifying management forecasts: CIG vs. researcher collected.” Journal of Accounting and Economics 55 (2013): 23-42.

CORE, J. and W. GUAY. "The use of equity grants to manage optimal equity incentive levels." Journal of Accounting and Economics 28 (1999): 151-184.

CORE, J. and W. GUAY. "Estimating the value of employee stock option portfolios and their sensitivities to price and volatility.” Journal of Accounting Research 40 (2002): 613-630.

COTTER, J.; I. TUNA and P. D. WYSOCKI. "Expectations management and beatable targets: How do analysts react to explicit earnings guidance?” Contemporary Accounting Research 23 (2006): 593-624.

DIETHER, K. B.; K. H. LEE and I. M. WERNER. "It's SHO time! Short-sale price tests and market quality.” The Journal of Finance 64 (2009): 37-73.

EDMANS, A., I. GOLDSTEIN and W. JIANG. "The real effects of financial markets: The impact of prices on takeovers.” The Journal of Finance 67 (2012):933-971.

FANG, V. W.; A. HUANG and J. KARPOFF. "Short selling and earnings management: A controlled experiment.” Available at SSRN 2286818 (2013).

GOLDSTEIN, I. and A. GUEMBEL. "Manipulation and the allocational role of prices." The Review of Economic Studies 75 (2008): 133-164.

GRAHAM, J. R.; C. R. HARVEY and S. RAJGOPAL. "The economic implications of corporate financial reporting.” Journal of Accounting and Economics 40 (2005): 3-73.

GROSSMAN, S. J. and J. E. STIGLITZ. "On the impossibility of informationally efficient markets.” The American Economic Review 70 (1980): 393-408.

GRULLON, G.; S. MICHENAUD and J. WESTON. "The real effects of short-selling constraints.” Rice University Working Paper (2012). 
HADLOCK, C. J. and J. R. PIERCE. "New evidence on measuring financial constraints: Moving beyond the KZ index.” Review of Financial Studies 23 (2010): 1909-1940.

HEALY, P. M. and K. G. PALEPU. "Information asymmetry, corporate disclosure, and the capital markets: A review of the empirical disclosure literature.” Journal of Accounting and Economics 31 (2001): 405-440.

HIRST, D. E.; L. KOONCE and S. VENKATARAMAN. "Management earnings forecasts: A review and framework.” Accounting Horizons 22 (2008): 315-338.

HONG, H. and J. C. STEIN. "Differences of opinion, short-sales constraints, and market crashes." The Review of Financial Studies 16 (2003): 487-525.

HUGHES, J. S. and S. PAE. "Voluntary disclosure of precision information." Journal of Accounting and Economics 37 (2004): 261-289.

HUTTON, A. and P. STOCKEN "Effect of reputation on the credibility of management forecasts.” Dartmouth University Working Paper (2007).

HUTTON, A. P.; G. S. MILLER and D. J. SKINNER. "The role of supplementary statements with management earnings forecasts.” Journal of Accounting Research 41 (2003): 867-890.

JENSEN, M. “Agency costs of overvalued equity.” Financial Management 34 (2005): 5-19.

JIANG, J.; K. PETRONI and I. WANG. "CFOs and CEOs: Who has the most influence on earnings management?” Journal of Financial Economics 96 (2010): 513-526.

JOHNSON, M. F.; R. KASZNIK and K. K. NELSON. "The impact of securities litigation reform on the disclosure of forward-looking information by high technology firms." Journal of Accounting Research 39 (2001): 297-327.

KARAMANOU, I. and N. VAFEAS. "The association between corporate boards, audit committees, and management earnings forecasts: An empirical analysis.” Journal of Accounting Research 43 (2005): 453-486.

KIM, I. and D. J. SKINNER. "Measuring securities litigation risk." Journal of Accounting and Economics 53 (2012): 290-310.

KIM, J.-B.; Y. LI and L. ZHANG. “CFOs versus CEOs: Equity incentives and crashes.” Journal of Financial Economics 101 (2011): 713-730.

KIM, O. and R. E. VERRECCHIA. "Trading volume and price reactions to public announcements.” Journal of Accounting Research 29 (1991): 302-321. 
KROSS, W. J.; B. T. RO and I. SUK. "Consistency in meeting or beating earnings expectations and management earnings forecasts.” Journal of Accounting and Economics 51 (2011): 37-57.

LEHAVY, R.; F. LI and K. MERKLEY. "The effect of annual report readability on analyst following and the properties of their earnings forecasts.” The Accounting Review 86 (2011): 1087-1115.

LI, F. "Annual report readability, current earnings, and earnings persistence." Journal of Accounting and Economics 45 (2008): 221-247.

LOUGHRAN, T. and B. MCDONALD. "Measuring readability in financial disclosures." The Journal of Finance 69 (2014): 1643-1671.

MILLER, E. M. "Risk, uncertainty, and divergence of opinion." The Journal of Finance 32 (1977): 1151-1168.

PATELL, J. M. "Corporate forecasts of earnings per share and stock price behavior: Empirical test.” Journal of Accounting Research 14 (1976): 246-276.

PENMAN, S. H. "An empirical investigation of the voluntary disclosure of corporate earnings forecasts.” Journal of Accounting Research 18 (1980): 132-160.

POWNALL, G.; C. WASLEY and G. WAYMIRE. "The stock price effects of alternative types of management earnings forecasts.” The Accounting Review 68 (1993): 896-912.

ROGERS, J. L. and P. C. STOCKEN. "Credibility of management forecasts.” The Accounting Review 80 (2005): 1233-1260.

ROGERS, J. L. and A. VAN BUSKIRK. "Shareholder litigation and changes in disclosure behavior.” Journal of Accounting and Economics 47 (2009): 136-156.

ROGERS, J. L. and A. VAN BUSKIRK. "Bundled forecasts in empirical accounting research.” Journal of Accounting and Economics 55 (2013): 43-65.

SKINNER, D. J. "Why firms voluntarily disclose bad news.” Journal of Accounting Research 32 (1994): 38-60.

WAYMIRE, G. "Additional evidence on the information content of management earnings forecasts.” Journal of Accounting Research 22 (1984): 703-718.

ZUO, L. "The Informational feedback effect of stock prices on corporate disclosure.” Cornell University Working Paper (2013). 
APPENDIX

Variable Definitions

Variable Name

Definition

$\underline{\text { Variables in market reaction regressions }}$

POST

1 if the current quarter is in $[0,+7]$ with quarter 0 being the fiscal quarter in which Reg SHO experiment was implemented, zero otherwise.

CAR $[-2,+2]$

Five-day value-weighted market adjusted cumulative abnormal returns around release of management forecast.

For non-bundled forecasts, five-day value-weighted market-adjusted cumulative abnormal returns around release of management forecast. For bundled forecasts, announcement period abnormal returns minus predicted

$C A R[-2,+2](R V)$ earnings announcement period abnormal returns. Predicted earnings announcement period returns are estimated using Eq. (5) of Rogers and Van Buskirk (2013), after replacing analyst forecast revisions with announcement period abnormal returns.

Management forecast news, computed as the difference between management

MFSURP forecast (point or mid-point of the range forecast) and the outstanding median analyst forecast at the time of management forecast, scaled by beginning-ofquarter share price.

$\operatorname{MFSURP}(R V)$

Management forecast news, calculated using the methodology proposed in Rogers and Van Buskirk (2013).

BADNEWS

1 if the management forecast conveys bad news (defined as MFSURP $<0$ ) and zero otherwise.

$B A D N E W S(R V)$

1 if management forecast conveys bad news (defined as $\operatorname{MFSURP}(R V)<0$ ) and zero otherwise.

GOODNEWS

1 if management forecast conveys good news (defined as MFSURP $>0$ ) and zero otherwise.

GOODNEWS(RV)

1 if management forecast conveys good news (defined as $\operatorname{MFSURP}(R V)>0$ ) and zero otherwise.

SIZE

Decile rank of the firm's beginning-of-quarter market capitalization.

$M B$

Decile rank of the firm’s beginning-of-quarter market-to-book ratio.

Variables in forecast precision regressions

Management forecast precision, defined as forecast width times negative 100;

PRECISION

forecast width is computed as the difference between high-end and low-end estimates scaled by beginning-of-quarter stock price and zero for point forecasts.

LAGSIZE

Logarithm of the firm’s beginning-of-quarter market capitalization. 


\begin{tabular}{|c|c|}
\hline$L A G B M$ & The firm's beginning-of-quarter book-to-market ratio. \\
\hline DLOSS & 1 if the firm reports a loss in the current quarter and zero otherwise. \\
\hline ANNRET & Cumulative daily returns over the 12 months prior to quarter $t$. \\
\hline RETVOL & Standard deviation of daily returns over the 12 months prior to quarter $t$. \\
\hline LITIGRISK & $\begin{array}{l}\text { The firm's ex ante litigation risk, estimated with Model (2) in Kim and } \\
\text { Skinner (2012). }\end{array}$ \\
\hline$A N A L Y C O V$ & Number of analysts following the firm in the current quarter. \\
\hline INSTOWN & Percentage of stocks held by institutional investors. \\
\hline MFHORIZON & $\begin{array}{l}\text { Management forecast horizon, computed as number of calendar days between } \\
\text { forecast release date and fiscal quarter-end. }\end{array}$ \\
\hline MFBIAS & $\begin{array}{l}\text { Management forecast bias/error, computed as the difference between actual } \\
\text { EPS and the management forecast (point or mid-point of the range forecast), } \\
\text { scaled by beginning-of-quarter stock price. }\end{array}$ \\
\hline ABSMFE & $\begin{array}{l}\text { Absolute value of management forecast error, computed as the absolute value } \\
\text { of the difference between actual EPS and management forecast (point or mid- } \\
\text { point of the range forecast), scaled by beginning-of-quarter stock price. }\end{array}$ \\
\hline ABSMFSURP & Absolute value of MFSURP. \\
\hline
\end{tabular}

$\operatorname{ABSMFSURP}(R V) \quad$ Absolute value of $\operatorname{MFSURP}(R V)$.

$\underline{\text { Variables in 10-K readability regressions }}$

InFOG Logarithm of 1 plus FOG, where FOG is the Gunning Fog Index of 10-K filings, taken from Li [2008].

InFILESIZE

Logarithm of FILESIZE, where FILESIZE is the document file size of $10-\mathrm{K}$ filings, taken from Loughran and McDonald [2013].

EARN Net income scaled by lagged total assets.

SIZE Logarithm of market value of equity at year-end.

MTB Market-to-book ratio at year-end.

AGE Number of years since a firm appears in CRSP monthly stock return files.

SI Special items scaled by book value of total assets.

RETVOL Standard deviation of stock returns in the preceding year.

EARNVOL

Standard deviation of operating earnings in the preceding five years. 
Logarithm of 1 plus number of business segments.

NGSEG

Logarithm of 1 plus number of geographic segments.

NITEMS

Number of non-missing items on Compustat for the firm-year.

SEO

Indicator variable that takes the value of 1 if a firm has a seasoned equity offering in the current year according to SDC Global New Issues database and zero otherwise.

Indicator variable that takes the value of 1 if a firm appears as an acquirer in the current year in SDC Platinum M\&A database and zero otherwise. 
TABLE 1

Descriptive Statistics for Management Forecast Sample

\begin{tabular}{|c|c|c|c|c|c|c|c|c|c|c|}
\hline \multicolumn{11}{|c|}{ Panel A: Event window $[-8,-1]$} \\
\hline \multirow[b]{2}{*}{ Variable } & \multicolumn{3}{|c|}{$\begin{array}{l}\text { Pilot Firms } \\
\text { (1) }\end{array}$} & \multicolumn{3}{|c|}{$\begin{array}{c}\text { Control Firms } \\
\text { (2) }\end{array}$} & \multicolumn{2}{|c|}{$\begin{array}{c}\text { Difference in } \\
\text { Mean }\end{array}$} & \multicolumn{2}{|c|}{$\begin{array}{c}\text { Difference in } \\
\text { Median }\end{array}$} \\
\hline & $\mathbf{N}$ & Mean & Median & $\mathbf{N}$ & Mean & Median & (1)-(2) & & (1)-(2) & \\
\hline$C A R[-2,+2]$ & 1,622 & 0.001 & 0.004 & 3,287 & 0.005 & 0.005 & -0.004 & & -0.001 & \\
\hline MFSURP & 1,622 & -0.027 & -0.020 & 3,287 & -0.069 & -0.013 & 0.042 & $* *$ & -0.007 & \\
\hline BADNEWS & 1,622 & 0.537 & 1.000 & 3,287 & 0.521 & 1.000 & 0.016 & & 0.000 & \\
\hline GOODNEWS & 1,622 & 0.326 & 0.000 & 3,287 & 0.343 & 0.000 & -0.017 & & 0.000 & \\
\hline$C A R[-2,+2](R V)$ & 1,622 & -0.004 & -0.001 & 3,287 & -0.001 & -0.001 & -0.003 & & 0.000 & \\
\hline $\operatorname{MFSURP}(R V)$ & 1,536 & 0.014 & 0.000 & 3,108 & -0.033 & 0.000 & 0.047 & $* *$ & 0.000 & \\
\hline$B A D N E W S(R V)$ & 1,622 & 0.512 & 1.000 & 3,287 & 0.499 & 0.000 & 0.013 & & 1.000 & \\
\hline GOODNEWS(RV) & 1,622 & 0.458 & 0.000 & 3,287 & 0.461 & 0.000 & -0.003 & & 0.000 & \\
\hline PRECISION & 1,622 & -0.186 & -0.115 & 3,287 & -0.182 & -0.116 & -0.004 & & 0.001 & \\
\hline LAGSIZE & 1,622 & 7.587 & 7.358 & 3,287 & 7.443 & 7.267 & 0.144 & $* * *$ & 0.091 & $* * *$ \\
\hline$L A G B M$ & 1,622 & 0.411 & 0.387 & 3,287 & 0.411 & 0.362 & 0.000 & & 0.025 & \\
\hline DLOSS & 1,622 & 0.030 & 0.000 & 3,287 & 0.037 & 0.000 & -0.007 & & 0.000 & \\
\hline ANNRET & 1,622 & 0.213 & 0.049 & 3,287 & 0.194 & 0.056 & 0.019 & & -0.007 & \\
\hline RETVOL & 1,622 & 0.026 & 0.024 & 3,287 & 0.026 & 0.024 & 0.000 & & 0.000 & \\
\hline LITIGRISK & 1,622 & 0.077 & 0.063 & 3,287 & 0.074 & 0.059 & 0.003 & & 0.004 & $* * *$ \\
\hline ANALYCOV & 1,622 & 10.957 & 9.000 & 3,287 & 10.445 & 9.000 & 0.512 & $* *$ & 0.000 & \\
\hline INSTOWN & 1,622 & 0.755 & 0.781 & 3,287 & 0.745 & 0.784 & 0.010 & $*$ & -0.003 & \\
\hline MFHORIZON & 1,622 & 55.359 & 63.000 & 3,287 & 55.279 & 63.000 & 0.080 & & 0.000 & \\
\hline ABSMFE & 1,622 & 0.289 & 0.110 & 3,287 & 0.293 & 0.117 & -0.004 & & -0.007 & \\
\hline ABSMFSURP & 1,622 & 0.239 & 0.079 & 3,287 & 0.254 & 0.080 & -0.015 & & -0.001 & \\
\hline ABSMFSURP $(R V)$ & 1,536 & 0.229 & 0.080 & 3,108 & 0.241 & 0.084 & -0.012 & & -0.004 & \\
\hline
\end{tabular}




\begin{tabular}{|c|c|c|c|c|c|c|c|c|c|c|}
\hline \multicolumn{11}{|c|}{ Panel B: Event window $[0,+7]$} \\
\hline \multirow[b]{2}{*}{ Variable } & \multicolumn{3}{|c|}{$\begin{array}{l}\text { Pilot Firms } \\
\text { (1) }\end{array}$} & \multicolumn{3}{|c|}{$\begin{array}{c}\text { Control Firms } \\
(2)\end{array}$} & \multicolumn{2}{|c|}{$\begin{array}{c}\text { Difference in } \\
\text { Mean }\end{array}$} & \multicolumn{2}{|c|}{$\begin{array}{c}\text { Difference in } \\
\text { Median }\end{array}$} \\
\hline & $\mathbf{N}$ & Mean & Median & $\mathbf{N}$ & Mean & Median & (1)-(2) & & (1)-(2) & \\
\hline$C A R[-2,+2]$ & 1,508 & -0.002 & 0.000 & 2,888 & 0.000 & 0.001 & -0.002 & & -0.001 & \\
\hline MFSURP & 1,508 & -0.072 & -0.035 & 2,888 & -0.096 & -0.029 & 0.024 & & -0.006 & \\
\hline BADNEWS & 1,508 & 0.601 & 1.000 & 2,888 & 0.584 & 1.000 & 0.017 & & 0.000 & \\
\hline $\operatorname{MFSURP}(R V)$ & 1,444 & -0.022 & -0.004 & 2,754 & -0.046 & 0.000 & 0.024 & & -0.004 & \\
\hline$B A D N E W S(R V)$ & 1,508 & 0.536 & 1.000 & 2,888 & 0.518 & 1.000 & 0.018 & & 0.000 & \\
\hline GOODNEWS(RV) & 1,508 & 0.435 & 0.000 & 2,888 & 0.453 & 0.000 & -0.018 & & 0.000 & \\
\hline PRECISION & 1,508 & -0.164 & -0.118 & 2,888 & -0.151 & -0.108 & -0.013 & & -0.010 & $* *$ \\
\hline LAGSIZE & 1,508 & 7.720 & 7.447 & 2,888 & 7.652 & 7.422 & 0.068 & & 0.025 & \\
\hline LITIGRISK & 1,508 & 0.047 & 0.039 & 2,888 & 0.048 & 0.039 & -0.001 & & 0.000 & \\
\hline ANALYCOV & 1,508 & 11.254 & 10.000 & 2,888 & 11.412 & 10.000 & -0.158 & & 0.000 & \\
\hline INSTOWN & 1,508 & 0.812 & 0.841 & 2,888 & 0.803 & 0.833 & 0.009 & $*$ & 0.008 & $* *$ \\
\hline MFHORIZON & 1,508 & 56.177 & 63.000 & 2,888 & 56.539 & 64.000 & -0.362 & & -1.000 & \\
\hline ABSMFE & 1,508 & 0.238 & 0.112 & 2,888 & 0.305 & 0.115 & -0.067 & $* * *$ & -0.003 & \\
\hline ABSMFSURP & 1,508 & 0.227 & 0.090 & 2,888 & 0.283 & 0.088 & -0.056 & $* * *$ & 0.002 & \\
\hline ABSMFSURP $(R V)$ & 1,444 & 0.210 & 0.080 & 2,754 & 0.267 & 0.084 & -0.057 & $* * *$ & -0.004 & $*$ \\
\hline
\end{tabular}


TABLE 2

Changes in Market Reactions to Management Forecasts around Reg SHO Experiment

\begin{tabular}{|c|c|c|c|c|}
\hline \multicolumn{5}{|c|}{ Panel A: Bad news management forecasts } \\
\hline \multicolumn{5}{|c|}{ Dependent Variable: $C A R[-2,+2]$} \\
\hline \multirow[b]{2}{*}{ Sample } & \multicolumn{2}{|c|}{$\begin{array}{c}\text { Traditional } \\
\text { News Measure }\end{array}$} & \multicolumn{2}{|c|}{$\begin{array}{l}\text { Rogers and Van Buskirk } \\
\text { News Measure }\end{array}$} \\
\hline & $\begin{array}{l}\text { Pilot Firms } \\
\text { (1) }\end{array}$ & $\begin{array}{c}\text { Control Firms } \\
\text { (2) }\end{array}$ & $\begin{array}{l}\text { Pilot Firms } \\
\text { (3) }\end{array}$ & $\begin{array}{c}\text { Control Firms } \\
\text { (4) }\end{array}$ \\
\hline MFSURP & $\begin{array}{l}-2.019 * * \\
(-2.15)\end{array}$ & $\begin{array}{l}4.204^{* * *} \\
(5.56)\end{array}$ & $\begin{array}{c}-1.714 \\
(-1.61)\end{array}$ & $\begin{array}{l}4.008^{* * *} \\
(4.89)\end{array}$ \\
\hline POST & $\begin{array}{l}-0.012 \\
(-1.04)\end{array}$ & $\begin{array}{l}-0.016^{*} \\
(-1.96)\end{array}$ & $\begin{array}{l}-0.004 \\
(-0.35)\end{array}$ & $\begin{array}{r}-0.010 \\
(-1.08)\end{array}$ \\
\hline$P O S T \times M F S U R P$ & $\begin{array}{l}8.684^{* * *} \\
(5.35)\end{array}$ & $\begin{array}{c}0.721 \\
(0.68) \\
\end{array}$ & $\begin{array}{l}10.352^{* * *} \\
(4.91)\end{array}$ & $\begin{array}{l}3.301^{* *} \\
(2.56) \\
\end{array}$ \\
\hline \multicolumn{5}{|l|}{ Control Variables: } \\
\hline SIZE & $\begin{array}{l}0.028^{* *} \\
(2.28)\end{array}$ & $\begin{array}{l}-0.009 \\
(-1.04)\end{array}$ & $\begin{array}{c}0.013 \\
(1.07)\end{array}$ & $\begin{array}{l}-0.007 \\
(-0.81)\end{array}$ \\
\hline MFSURP $\times$ SIZE & $\begin{array}{l}5.839 * \\
(1.89)\end{array}$ & $\begin{array}{l}-5.188^{* * *} \\
(-3.21)\end{array}$ & $\begin{array}{c}2.225 \\
(0.68)\end{array}$ & $\begin{array}{l}-4.300^{* *} \\
(-2.32)\end{array}$ \\
\hline$M B$ & $\begin{array}{l}-0.037 * * * \\
(-3.17)\end{array}$ & $\begin{array}{l}-0.029^{* * *} \\
(-3.65)\end{array}$ & $\begin{array}{l}-0.005 \\
(-0.48)\end{array}$ & $\begin{array}{l}-0.023^{* * *} \\
(-2.82)\end{array}$ \\
\hline$M F S U R P \times M B$ & $\begin{array}{l}6.866^{* *} \\
(2.31)\end{array}$ & $\begin{array}{c}0.885 \\
(0.58)\end{array}$ & $\begin{array}{l}8.905^{* * *} \\
(2.80)\end{array}$ & $\begin{array}{c}0.089 \\
(0.05)\end{array}$ \\
\hline$P O S T \times$ SIZE & $\begin{array}{r}0.002 \\
(0.09)\end{array}$ & $\begin{array}{l}-0.000 \\
(-0.04)\end{array}$ & $\begin{array}{c}0.014 \\
(0.77)\end{array}$ & $\begin{array}{l}-0.006 \\
(-0.45)\end{array}$ \\
\hline$P O S T \times M F S U R P \times S I Z E$ & $\begin{array}{l}-9.018^{* *} \\
(-2.08)\end{array}$ & $\begin{array}{l}-2.483 \\
(-1.22)\end{array}$ & $\begin{array}{l}-6.746 \\
(-1.48)\end{array}$ & $\begin{array}{l}-6.912^{* * *} \\
(-2.84)\end{array}$ \\
\hline$P O S T \times M B$ & $\begin{array}{c}0.019 \\
(1.20)\end{array}$ & $\begin{array}{l}0.022^{* *} \\
(2.04)\end{array}$ & $\begin{array}{l}-0.011 \\
(-0.66)\end{array}$ & $\begin{array}{l}0.017 \\
(1.53)\end{array}$ \\
\hline$P O S T \times M F S U R P \times M B$ & $\begin{array}{l}-8.101^{* *} \\
(-2.09)\end{array}$ & $\begin{array}{c}2.189 \\
(1.18)\end{array}$ & $\begin{array}{l}-14.016^{* * *} \\
(-3.39)\end{array}$ & $\begin{array}{l}3.817^{*} \\
(1.85)\end{array}$ \\
\hline Intercept & $\begin{array}{l}-0.009 \\
(-1.20)\end{array}$ & $\begin{array}{l}0.009^{*} \\
(1.67)\end{array}$ & $\begin{array}{l}-0.026 * * * \\
(-3.30)\end{array}$ & $\begin{array}{l}-0.002 \\
(-0.36)\end{array}$ \\
\hline $\begin{array}{l}\text { Observations } \\
\text {. }\end{array}$ & 1,777 & 3,400 & 1,492 & 2,860 \\
\hline Adjusted $R^{2}$ & 0.068 & 0.032 & 0.047 & 0.034 \\
\hline $\begin{array}{l}\text { Comparing coefficients on } \\
P O S T \times \text { MFSURP }\end{array}$ & $\begin{array}{r}\text { Chi-s } \\
p--\end{array}$ & $\begin{array}{l}\mathrm{ed} 4.68 \\
0.03\end{array}$ & $\begin{array}{r}\text { Chi-s } \\
p-\overline{1}\end{array}$ & $\begin{array}{l}0.09 \\
0.02\end{array}$ \\
\hline
\end{tabular}




\begin{tabular}{|c|c|c|c|c|}
\hline \multicolumn{5}{|c|}{ Panel B: Good news management forecasts } \\
\hline \multicolumn{5}{|c|}{ Dependent Variable: $C A R[-2,+2]$} \\
\hline \multirow[b]{2}{*}{ Sample } & \multicolumn{2}{|c|}{$\begin{array}{c}\text { Traditional } \\
\text { News Measure }\end{array}$} & \multicolumn{2}{|c|}{$\begin{array}{l}\text { Rogers and Van Buskirk } \\
\text { News Measure }\end{array}$} \\
\hline & $\begin{array}{l}\text { Pilot Firms } \\
\text { (1) }\end{array}$ & $\begin{array}{l}\text { Control Firms } \\
\text { (2) }\end{array}$ & $\begin{array}{l}\text { Pilot Firms } \\
\text { (3) }\end{array}$ & $\begin{array}{c}\text { Control Firms } \\
\text { (4) }\end{array}$ \\
\hline$\overline{M F S U R P}$ & $\begin{array}{c}-0.163 \\
(-0.20)\end{array}$ & $\begin{array}{l}1.157 \\
(1.26)\end{array}$ & $\begin{array}{c}0.283 \\
(0.36)\end{array}$ & $\begin{array}{c}1.286 \\
(1.34)\end{array}$ \\
\hline POST & $\begin{array}{l}-0.003 \\
(-0.22)\end{array}$ & $\begin{array}{l}0.032^{* * *} \\
(2.79)\end{array}$ & $\begin{array}{l}-0.007 \\
(-0.56)\end{array}$ & $\begin{array}{r}0.011 \\
(1.09)\end{array}$ \\
\hline POST $\times$ MFSURP & $\begin{array}{r}1.480 \\
(0.79)\end{array}$ & $\begin{array}{l}-1.592 \\
(-0.92)\end{array}$ & $\begin{array}{c}0.203 \\
(0.11)\end{array}$ & $\begin{array}{c}0.270 \\
(0.16)\end{array}$ \\
\hline \multicolumn{5}{|l|}{ Control Variables: } \\
\hline SIZE & $\begin{array}{l}-0.043^{* * *} \\
(-3.24)\end{array}$ & $\begin{array}{l}-0.047^{* * *} \\
(-4.76)\end{array}$ & $\begin{array}{l}-0.037 * * * \\
(-3.16)\end{array}$ & $\begin{array}{l}-0.039 * * * \\
(-4.44)\end{array}$ \\
\hline MFSURP $\times$ SIZE & $\begin{array}{l}-1.259 \\
(-0.64)\end{array}$ & $\begin{array}{l}-2.596 \\
(-1.40)\end{array}$ & $\begin{array}{l}-2.399 \\
(-1.28)\end{array}$ & $\begin{array}{l}-7.647^{* * *} \\
(-3.57)\end{array}$ \\
\hline$M B$ & $\begin{array}{c}0.012 \\
(0.98)\end{array}$ & $\begin{array}{c}0.005 \\
(0.51)\end{array}$ & $\begin{array}{l}-0.015 \\
(-1.42)\end{array}$ & $\begin{array}{l}-0.014^{*} \\
(-1.73)\end{array}$ \\
\hline$M F S U R P \times M B$ & $\begin{array}{c}1.183 \\
(0.71)\end{array}$ & $\begin{array}{c}0.668 \\
(0.38)\end{array}$ & $\begin{array}{l}2.904^{*} \\
(1.77)\end{array}$ & $\begin{array}{l}7.561^{* * * *} \\
(3.84)\end{array}$ \\
\hline$P O S T \times S I Z E$ & $\begin{array}{c}0.023 \\
(1.07)\end{array}$ & $\begin{array}{l}-0.009 \\
(-0.54)\end{array}$ & $\begin{array}{r}0.007 \\
(0.36)\end{array}$ & $\begin{array}{l}-0.003 \\
(-0.25)\end{array}$ \\
\hline$P O S T \times M F S U R P \times S I Z E$ & $\begin{array}{l}-1.506 \\
(-0.50)\end{array}$ & $\begin{array}{l}-1.294 \\
(-0.45)\end{array}$ & $\begin{array}{l}1.590 \\
(0.54)\end{array}$ & $\begin{array}{r}3.017 \\
(0.96)\end{array}$ \\
\hline$P O S T \times M B$ & $\begin{array}{l}-0.016 \\
(-0.81)\end{array}$ & $\begin{array}{l}-0.031^{* *} \\
(-2.04)\end{array}$ & $\begin{array}{c}0.007 \\
(0.44)\end{array}$ & $\begin{array}{l}-0.014 \\
(-1.12)\end{array}$ \\
\hline$P O S T \times M F S U R P \times M B$ & $\begin{array}{l}-1.599 \\
(-0.62)\end{array}$ & $\begin{array}{c}2.713 \\
(0.97)\end{array}$ & $\begin{array}{l}-3.499 \\
(-1.38)\end{array}$ & $\begin{array}{l}-5.061^{*} \\
(-1.71)\end{array}$ \\
\hline Intercept & $\begin{array}{l}0.056^{* * *} \\
(6.28)\end{array}$ & $\begin{array}{l}0.062^{* * *} \\
(8.90)\end{array}$ & $\begin{array}{l}0.051^{* * *} \\
(6.51)\end{array}$ & $\begin{array}{l}0.052^{* * *} \\
(8.61)\end{array}$ \\
\hline Observations & 971 & 2,002 & 1,401 & 2,852 \\
\hline Adjusted $R^{2}$ & 0.014 & 0.043 & 0.019 & 0.045 \\
\hline $\begin{array}{l}\text { Comparing coefficients on } \\
P O S T \times M F S U R P\end{array}$ & \multicolumn{2}{|c|}{$\begin{array}{c}\text { Chi-squared } 1.48 \\
p \text {-value } 0.22\end{array}$} & \multicolumn{2}{|c|}{$\begin{array}{c}\text { Chi-squared } 0.00 \\
p \text {-value } 0.98 \\
\end{array}$} \\
\hline \multicolumn{5}{|c|}{$\begin{array}{l}\text { This table presents results on changes in market reactions to management forecasts around the Reg SHO experiment. } \\
\text { The sample includes } 8,150(8,605) \text { quarterly point and range good news and bad news management forecasts } \\
\text { released in firm-quarters in the event window }[-8,+7] \text { with required data under the traditional (Rogers and Van } \\
\text { Buskirk) methodology, where event quarter } 0 \text { is the fiscal quarter in which the Reg SHO experiment was } \\
\text { implemented. In the columns under "Rogers and Van Buskirk News Measure," the dependent variable, CAR [-2, } \\
+2] \text {, is adjusted market reaction following the method of Rogers and Van Buskirk (2013). } t \text {-statistics reported in } \\
\text { parentheses are based on heteroscedasticity-robust standard errors clustered by firm. *, **, and *** indicate } \\
\text { statistical significance at the } 10 \%, 5 \% \text {, and } 1 \% \text { levels (two-sided), respectively. The appendix contains the variable } \\
\text { definitions. }\end{array}$} \\
\hline
\end{tabular}


TABLE 3

Changes in Likelihoods of Issuing Management around Reg SHO Experiment

\begin{tabular}{|c|c|c|c|c|c|}
\hline \multirow[b]{2}{*}{ Dependent Variable: } & \multirow[b]{2}{*}{$\begin{array}{l}\text { Probability of } \\
\text { Issuing } \\
\text { Forecasts } \\
(1)\end{array}$} & \multicolumn{2}{|c|}{$\begin{array}{c}\text { Traditional } \\
\text { News Measure }\end{array}$} & \multicolumn{2}{|c|}{$\begin{array}{c}\text { Rogers and Van Buskirk } \\
\text { News Measure }\end{array}$} \\
\hline & & $\begin{array}{l}\text { Probability of } \\
\text { Issuing } \\
\text { Good News } \\
\text { Forecasts } \\
\text { (2) }\end{array}$ & $\begin{array}{l}\text { Probability of } \\
\text { Issuing } \\
\text { Bad News } \\
\text { Forecasts } \\
\text { (3) }\end{array}$ & $\begin{array}{l}\text { Probability of } \\
\text { Issuing } \\
\text { Good News } \\
\text { Forecasts } \\
\text { (4) }\end{array}$ & $\begin{array}{l}\text { Probability of } \\
\text { Issuing } \\
\text { Bad News } \\
\text { Forecasts } \\
\text { (5) }\end{array}$ \\
\hline PILOT & - & - & - & - & - \\
\hline POST & $\begin{array}{l}-0.281^{*} \\
(-1.78)\end{array}$ & $\begin{array}{l}-0.460^{* *} \\
(-2.54)\end{array}$ & $\begin{array}{r}0.084 \\
(0.57)\end{array}$ & $\begin{array}{c}-0.183 \\
(-1.16)\end{array}$ & $\begin{array}{l}-0.116 \\
(-0.78)\end{array}$ \\
\hline$P O S T \times P I L O T$ & $\begin{array}{r}0.121 \\
(1.32) \\
\end{array}$ & $\begin{array}{r}0.082 \\
(0.78) \\
\end{array}$ & $\begin{array}{r}0.122 \\
(1.41) \\
\end{array}$ & $\begin{array}{c}-0.020 \\
(-0.21) \\
\end{array}$ & $\begin{array}{c}0.126 \\
(1.43) \\
\end{array}$ \\
\hline \multicolumn{6}{|l|}{ Control Variables: } \\
\hline LAGSIZE & $\begin{array}{l}0.702^{* * *} \\
(6.76)\end{array}$ & $\begin{array}{r}0.129 \\
(1.01)\end{array}$ & $\begin{array}{l}0.453^{* * *} \\
(4.37)\end{array}$ & $\begin{array}{l}0.267^{* *} \\
(2.37)\end{array}$ & $\begin{array}{l}0.459^{* * *} \\
(4.41)\end{array}$ \\
\hline$L A G B M$ & $\begin{array}{c}0.284 \\
(1.41)\end{array}$ & $\begin{array}{l}-0.429 \\
(-1.48)\end{array}$ & $\begin{array}{r}0.244 \\
(1.20)\end{array}$ & $\begin{array}{c}-0.092 \\
(-0.37)\end{array}$ & $\begin{array}{r}0.241 \\
(1.21)\end{array}$ \\
\hline DLOSS & $\begin{array}{l}-1.083^{* * *} \\
(-10.34)\end{array}$ & $\begin{array}{l}-1.603^{* * *} \\
(-8.40)\end{array}$ & $\begin{array}{l}-0.313^{* * *} \\
(-2.94)\end{array}$ & $\begin{array}{l}-1.325^{* * *} \\
(-8.51)\end{array}$ & $\begin{array}{l}-0.381^{* * *} \\
(-3.54)\end{array}$ \\
\hline ANNRET & $\begin{array}{l}-0.122^{* *} \\
(-2.23)\end{array}$ & $\begin{array}{l}0.150^{* *} \\
(2.34)\end{array}$ & $\begin{array}{l}-0.264^{* * *} \\
(-4.48)\end{array}$ & $\begin{array}{r}0.054 \\
(0.93)\end{array}$ & $\begin{array}{l}-0.181^{* * *} \\
(-3.16)\end{array}$ \\
\hline RETVOL & $\begin{array}{l}-22.926 * * * \\
(-5.01)\end{array}$ & $\begin{array}{l}-12.678^{* *} \\
(-2.33)\end{array}$ & $\begin{array}{l}-23.254^{* * *} \\
(-5.05)\end{array}$ & $\begin{array}{l}-16.859 * * * \\
(-3.48)\end{array}$ & $\begin{array}{l}-6.315 \\
(-1.41)\end{array}$ \\
\hline LITIGRISK & $\begin{array}{l}2.277^{* * *} \\
(3.66)\end{array}$ & $\begin{array}{l}-5.342^{* * *} \\
(-7.04)\end{array}$ & $\begin{array}{l}6.972^{* * * *} \\
(11.22)\end{array}$ & $\begin{array}{l}-2.251^{* * *} \\
(-3.55)\end{array}$ & $\begin{array}{l}4.287^{* * *} \\
(7.11)\end{array}$ \\
\hline ANALYCOV & $\begin{array}{l}0.075^{* * *} \\
(6.30)\end{array}$ & $\begin{array}{l}0.023^{*} \\
(1.71)\end{array}$ & $\begin{array}{l}0.066^{* * *} \\
(5.87)\end{array}$ & $\begin{array}{l}0.030^{* * *} \\
(2.61)\end{array}$ & $\begin{array}{l}0.081^{* * *} \\
(7.10)\end{array}$ \\
\hline INSTOWN & $\begin{array}{l}0.885^{* * *} \\
(2.76)\end{array}$ & $\begin{array}{l}1.148^{* * *} \\
(2.94)\end{array}$ & $\begin{array}{l}-0.652^{* *} \\
(-2.08)\end{array}$ & $\begin{array}{l}0.933^{* * *} \\
(2.64)\end{array}$ & $\begin{array}{r}-0.040 \\
(-0.12)\end{array}$ \\
\hline $\begin{array}{l}\text { Firm fixed effects } \\
\text { Quarter fixed effects }\end{array}$ & $\begin{array}{l}\text { Yes } \\
\text { Yes }\end{array}$ & $\begin{array}{l}\text { Yes } \\
\text { Yes }\end{array}$ & $\begin{array}{l}\text { Yes } \\
\text { Yes }\end{array}$ & $\begin{array}{l}\text { Yes } \\
\text { Yes }\end{array}$ & $\begin{array}{l}\text { Yes } \\
\text { Yes }\end{array}$ \\
\hline Observations & 34,096 & 34,096 & 34,096 & 34,096 & 34,096 \\
\hline Adjusted $R^{2}$ & 0.042 & 0.037 & 0.036 & 0.031 & 0.024 \\
\hline
\end{tabular}

This table presents results on changes in likelihoods of issuing management forecasts around the Reg SHO experiment. The sample includes 34,096 firm-quarters in the event window $[-8,+7]$ with required data. Event quarter 0 is the fiscal quarter in which the Reg SHO experiment was implemented. T-statistics reported in parentheses are based on heteroscedasticity-robust standard errors clustered by firm. *, **, and *** indicate statistical significance at the $10 \%, 5 \%$, and $1 \%$ levels (two-sided), respectively. The appendix contains the variable definitions. 
TABLE 4

Changes in Management Forecast Precision around Reg SHO Experiment

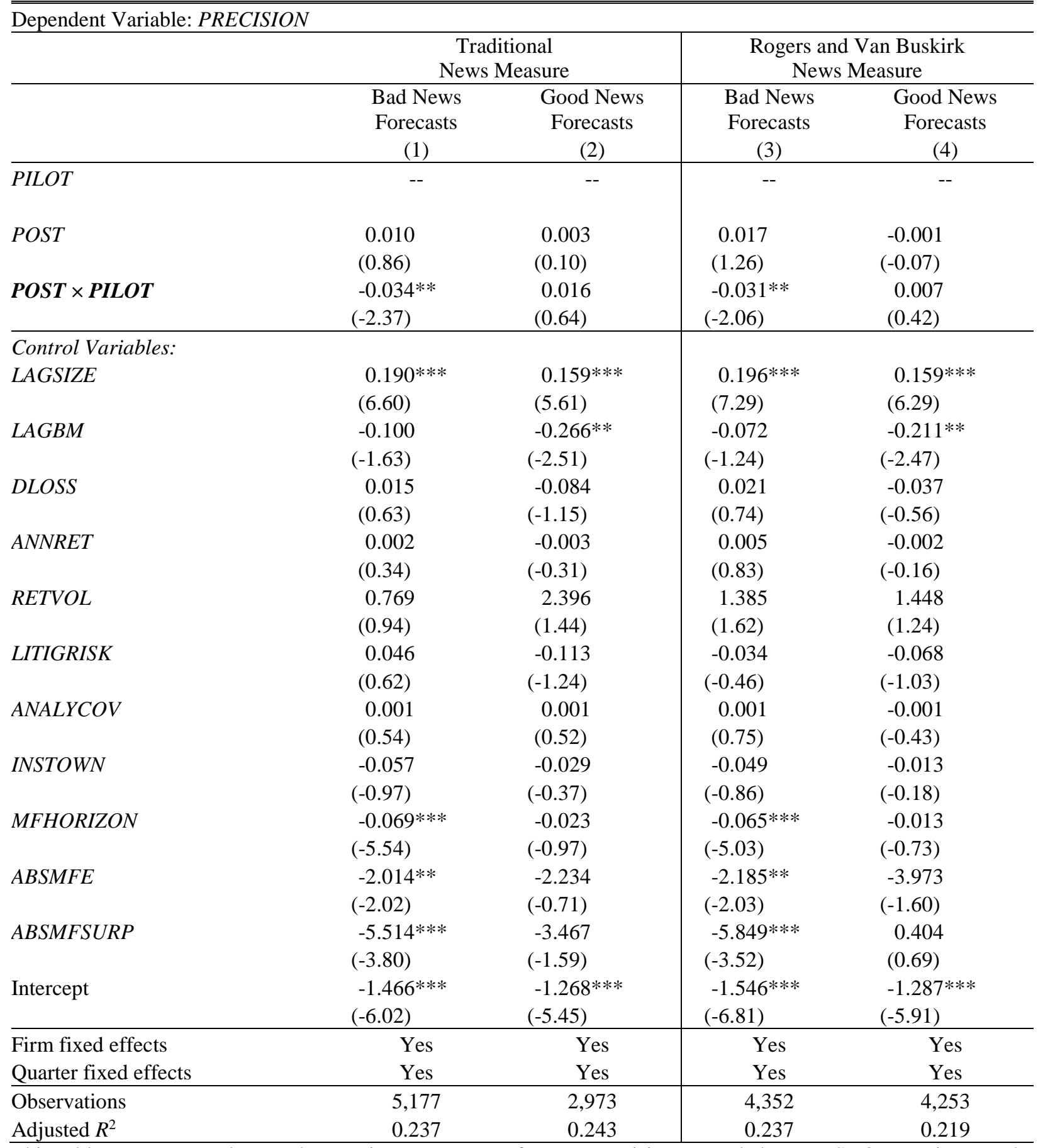

This table presents results on changes in management forecast precision around the Reg SHO experiment. The sample includes 8,150 $(8,605)$ quarterly point and range good news and bad news management forecasts released in firm-quarters in the event window $[-8,+7]$ with required data under the traditional (Rogers and Van Buskirk) methodology, where event quarter 0 is the fiscal quarter in which the Reg SHO experiment was implemented. The coefficients on MFHORIZON are multiplied by 100 for exposition. T-statistics reported in parentheses are based on heteroscedasticity-robust standard errors clustered by firm. *, **, and *** indicate statistical significance at the $10 \%$, $5 \%$, and $1 \%$ levels (two-sided), respectively. The appendix contains the variable definitions. 
TABLE 5

Changes in Annual Report Readability around Reg SHO

\begin{tabular}{|c|c|c|c|c|}
\hline \multirow[t]{2}{*}{ Dependent Variable: } & \multicolumn{2}{|c|}{$\ln F O G$} & \multicolumn{2}{|c|}{$\operatorname{lnFILESIZE~}$} \\
\hline & $\begin{array}{c}\text { Bad News Repor } \\
\text { (1) }\end{array}$ & $\begin{array}{c}\text { Good News Report } \\
\text { (2) }\end{array}$ & $\begin{array}{c}\text { Bad News Report } \\
\text { (3) }\end{array}$ & $\begin{array}{c}\text { Good News Report } \\
\text { (4) }\end{array}$ \\
\hline PILOT & -- & -- & -- & -- \\
\hline POST & $\begin{array}{l}0.009 \\
(0.25)\end{array}$ & $\begin{array}{c}0.002 \\
(0.08)\end{array}$ & $\begin{array}{c}0.162 \\
(0.56)\end{array}$ & $\begin{array}{c}0.019 \\
(0.21)\end{array}$ \\
\hline$P O S T \times P I L O T$ & $\begin{array}{l}0.032^{* * *} \\
(2.18)\end{array}$ & $\begin{array}{r}-0.002 \\
(-0.16) \\
\end{array}$ & $\begin{array}{l}0.133^{*} \\
(1.81)\end{array}$ & $\begin{array}{c}0.029 \\
(0.76)\end{array}$ \\
\hline \multicolumn{5}{|l|}{ Control Variables: } \\
\hline$E A R N$ & $\begin{array}{c}0.024 \\
(0.49)\end{array}$ & $\begin{array}{l}-0.024 \\
(-0.31)\end{array}$ & $\begin{array}{l}-0.210 \\
(-0.73)\end{array}$ & $\begin{array}{l}-0.630 * \\
(-1.78)\end{array}$ \\
\hline SIZE & $\begin{array}{l}-0.014 \\
(-1.60)\end{array}$ & $\begin{array}{c}0.002 \\
(0.11)\end{array}$ & $\begin{array}{c}0.007 \\
(0.12)\end{array}$ & $\begin{array}{c}0.001 \\
(0.02)\end{array}$ \\
\hline MTB & $\begin{array}{l}-0.006 \\
(-1.24)\end{array}$ & $\begin{array}{c}0.001 \\
(0.22)\end{array}$ & $\begin{array}{l}-0.032 \\
(-1.34)\end{array}$ & $\begin{array}{r}0.028 \\
(1.42)\end{array}$ \\
\hline$A G E$ & $\begin{array}{c}0.003 \\
(0.11)\end{array}$ & $\begin{array}{l}-0.011 \\
(-0.39)\end{array}$ & $\begin{array}{l}-0.164 \\
(-1.14)\end{array}$ & $\begin{array}{l}-0.239 * * \\
(-2.39)\end{array}$ \\
\hline$S I$ & $\begin{array}{l}-0.043 \\
(-0.87)\end{array}$ & $\begin{array}{l}-0.036 \\
(-0.65)\end{array}$ & $\begin{array}{l}-0.852^{* *} \\
(-2.25)\end{array}$ & $\begin{array}{l}-0.247 \\
(-0.80)\end{array}$ \\
\hline RETVOL & $\begin{array}{c}0.046 \\
(0.97)\end{array}$ & $\begin{array}{c}0.036 \\
(0.55)\end{array}$ & $\begin{array}{c}0.189 \\
(0.75)\end{array}$ & $\begin{array}{l}0.300 \\
(1.24)\end{array}$ \\
\hline EARNVOL & $\begin{array}{c}0.053 \\
(0.76)\end{array}$ & $\begin{array}{l}-0.119 * * \\
(-2.38)\end{array}$ & $\begin{array}{l}-0.529 * * \\
(-2.03)\end{array}$ & $\begin{array}{c}0.246 \\
(1.20)\end{array}$ \\
\hline NBSEG & $\begin{array}{l}-0.000 \\
(-0.02)\end{array}$ & $\begin{array}{c}-0.008 \\
(-0.33)\end{array}$ & $\begin{array}{l}-0.029 \\
(-0.40)\end{array}$ & $\begin{array}{c}0.035 \\
(0.81)\end{array}$ \\
\hline NGSEG & $\begin{array}{l}0.019 * \\
(1.74)\end{array}$ & $\begin{array}{c}-0.005 \\
(-0.54)\end{array}$ & $\begin{array}{c}0.016 \\
(0.24)\end{array}$ & $\begin{array}{c}-0.023 \\
(-0.47)\end{array}$ \\
\hline NITEMS & $\begin{array}{c}-0.171 \\
(-1.16)\end{array}$ & $\begin{array}{c}-0.027 \\
(-0.40)\end{array}$ & $\begin{array}{c}0.532 \\
(1.22)\end{array}$ & $\begin{array}{l}0.634^{* *} \\
(2.26)\end{array}$ \\
\hline SEO & $\begin{array}{c}-0.002 \\
(-0.29)\end{array}$ & $\begin{array}{c}0.004 \\
(0.46)\end{array}$ & $\begin{array}{c}-0.006 \\
(-0.12)\end{array}$ & $\begin{array}{c}0.018 \\
(0.47)\end{array}$ \\
\hline$M A$ & $\begin{array}{c}0.004 \\
(0.24)\end{array}$ & $\begin{array}{c}-0.001 \\
(-0.16)\end{array}$ & $\begin{array}{c}0.005 \\
(0.15)\end{array}$ & $\begin{array}{c}0.027 \\
(1.28)\end{array}$ \\
\hline Intercept & $\begin{array}{l}4.043^{* * *} \\
(5.00)\end{array}$ & $\begin{array}{l}3.224^{* * * *} \\
(8.03)\end{array}$ & $\begin{array}{c}-1.710 \\
(-0.73) \\
\end{array}$ & $\begin{array}{c}-2.552 \\
(-1.59) \\
\end{array}$ \\
\hline Firm fixed effects & Yes & Yes & Yes & Yes \\
\hline Year fixed effects & Yes & Yes & Yes & Yes \\
\hline Observations & 2,700 & 4,771 & 2,382 & 4,330 \\
\hline Adjusted $R^{2}$ & 0.003 & 0.001 & 0.167 & 0.205 \\
\hline
\end{tabular}


TABLE 6

Changes in Other Management Forecast Characteristics around Reg SHO Experiment

\begin{tabular}{|c|c|c|c|c|}
\hline \multirow[t]{2}{*}{ Dependent Variable: } & \multicolumn{2}{|c|}{ MFSURP } & \multirow[t]{2}{*}{ MFBIAS } & ABSMFE \\
\hline & $\begin{array}{c}\text { Traditional } \\
\text { News Measure } \\
(1)\end{array}$ & $\begin{array}{c}\text { Rogers and Van } \\
\text { Buskirk } \\
\text { News Measure } \\
(2) \\
\end{array}$ & & (4) \\
\hline PILOT & -- & -- & -- & -- \\
\hline POST & $\begin{array}{c}-0.022 \\
(-0.81)\end{array}$ & $\begin{array}{c}-0.024 \\
(-0.67)\end{array}$ & $\begin{array}{c}-0.058 \\
(-1.06)\end{array}$ & $\begin{array}{c}-0.082 \\
(-1.39)\end{array}$ \\
\hline$P O S T \times P I L O T$ & $\begin{array}{c}0.000 \\
(0.03) \\
\end{array}$ & $\begin{array}{c}-0.047 \\
(-1.00)\end{array}$ & $\begin{array}{c}0.011 \\
(0.33) \\
\end{array}$ & $\begin{array}{c}-0.029 \\
(-1.00)\end{array}$ \\
\hline Control Variables: & & & & \\
\hline LAGSIZE & $\begin{array}{c}0.050 \\
(1.50)\end{array}$ & $\begin{array}{c}0.012 \\
(0.20)\end{array}$ & $\begin{array}{l}0.202^{* *} \\
(2.06)\end{array}$ & $\begin{array}{l}-0.208 * * * \\
(-4.68)\end{array}$ \\
\hline$L A G B M$ & $\begin{array}{l}-0.277^{* * *} \\
(-2.78)\end{array}$ & $\begin{array}{c}-0.227 \\
(-1.30)\end{array}$ & $\begin{array}{c}0.311 \\
(1.41)\end{array}$ & $\begin{array}{c}0.366^{*} \\
(1.80)\end{array}$ \\
\hline DLOSS & $\begin{array}{l}-0.392^{* * *} \\
(-4.50)\end{array}$ & $\begin{array}{l}-0.360 * * * \\
(-3.87)\end{array}$ & $\begin{array}{l}1.010^{* * *} \\
(4.49)\end{array}$ & $\begin{array}{l}0.793^{* * * *} \\
(5.25)\end{array}$ \\
\hline ANNRET & $\begin{array}{c}-0.001 \\
(-0.09)\end{array}$ & $\begin{array}{c}-0.006 \\
(-0.46)\end{array}$ & $\begin{array}{c}-0.014 \\
(-0.80)\end{array}$ & $\begin{array}{c}0.004 \\
(0.25)\end{array}$ \\
\hline RETVOL & $\begin{array}{c}0.938 \\
(0.56)\end{array}$ & $\begin{array}{l}-0.046 \\
(-0.02)\end{array}$ & $\begin{array}{l}-3.704 \\
(-1.59)\end{array}$ & $\begin{array}{c}1.526 \\
(0.62)\end{array}$ \\
\hline LITIGRISK & $\begin{array}{l}-1.071^{* * *} \\
(-6.08)\end{array}$ & $\begin{array}{l}-0.944 * * * \\
(-4.47)\end{array}$ & $\begin{array}{l}1.708 * * * \\
(5.52)\end{array}$ & $\begin{array}{c}0.134 \\
(0.66)\end{array}$ \\
\hline ANALYCOV & $\begin{array}{l}-0.002 \\
(-0.61)\end{array}$ & $\begin{array}{c}-0.001 \\
(-0.21)\end{array}$ & $\begin{array}{c}0.003 \\
(0.75)\end{array}$ & $\begin{array}{l}-0.002 \\
(-0.54)\end{array}$ \\
\hline INSTOWN & $\begin{array}{c}-0.016 \\
(-0.13)\end{array}$ & $\begin{array}{c}0.003 \\
(0.01)\end{array}$ & $\begin{array}{l}-0.422 * * \\
(-2.02)\end{array}$ & $\begin{array}{c}-0.211 \\
(-1.29)\end{array}$ \\
\hline MFHORIZON & $\begin{array}{c}0.025 \\
(0.91)\end{array}$ & $\begin{array}{l}0.115^{* *} \\
(2.55)\end{array}$ & $\begin{array}{c}0.033 \\
(1.13)\end{array}$ & $\begin{array}{l}0.172 * * * \\
(5.97)\end{array}$ \\
\hline Intercept & $\begin{array}{c}-0.278 \\
(-0.90)\end{array}$ & $\begin{array}{r}0.060 \\
(0.09) \\
\end{array}$ & $\begin{array}{l}-1.407^{*} \\
(-1.67)\end{array}$ & $\begin{array}{l}1.579 * * * \\
(3.65)\end{array}$ \\
\hline $\begin{array}{l}\text { Firm fixed effects } \\
\text { Quarter fixed effects }\end{array}$ & $\begin{array}{l}\text { Yes } \\
\text { Yes }\end{array}$ & $\begin{array}{l}\text { Yes } \\
\text { Yes }\end{array}$ & $\begin{array}{l}\text { Yes } \\
\text { Yes }\end{array}$ & $\begin{array}{l}\text { Yes } \\
\text { Yes }\end{array}$ \\
\hline $\begin{array}{l}\text { Observations } \\
\text { Adjusted } R^{2}\end{array}$ & $\begin{array}{l}9,305 \\
0.061\end{array}$ & $\begin{array}{l}8,842 \\
0.012 \\
\end{array}$ & $\begin{array}{l}9,305 \\
0.091 \\
\end{array}$ & $\begin{array}{l}9,305 \\
0.101\end{array}$ \\
\hline
\end{tabular}

This table presents results on changes in other management forecast characteristics around the Reg SHO experiment. The sample includes 9,305 quarterly point and range management forecasts released in firm-quarters in the event window [-8, +7] with required data. Event quarter 0 is the fiscal quarter in which the Reg SHO experiment was implemented. All dependent variables and the coefficients on MFHORIZON are multiplied by 100 for exposition. Tstatistics reported in parentheses are based on heteroscedasticity-robust standard errors clustered by firm. *, **, and *** indicate statistical significance at the 10\%, 5\%, and 1\% levels (two-sided), respectively. The appendix contains the variable definitions. 
TABLE 7

Changes in Management Forecast Precision around the End of Reg SHO Experiment

\begin{tabular}{|c|c|c|c|c|}
\hline \multicolumn{5}{|c|}{ Dependent Variable: PRECISION } \\
\hline & \multicolumn{2}{|c|}{$\begin{array}{c}\text { Traditional } \\
\text { News Measure }\end{array}$} & \multicolumn{2}{|c|}{$\begin{array}{c}\text { Rogers and Van Buskirk } \\
\text { News Measure }\end{array}$} \\
\hline & $\begin{array}{c}\text { Bad News } \\
\text { Forecasts } \\
\text { (1) }\end{array}$ & $\begin{array}{c}\text { Good News } \\
\text { Forecasts } \\
\text { (2) }\end{array}$ & $\begin{array}{c}\text { Bad News } \\
\text { Forecasts } \\
\text { (3) }\end{array}$ & $\begin{array}{c}\text { Good News } \\
\text { Forecasts } \\
\text { (4) }\end{array}$ \\
\hline PILOT & -- & -- & -- & -- \\
\hline POST_END & $\begin{array}{l}-0.019 * * \\
(-1.97)\end{array}$ & $\begin{array}{l}-0.009 \\
(-0.80)\end{array}$ & $\begin{array}{l}-0.025^{* *} \\
(-2.55)\end{array}$ & $\begin{array}{c}0.004 \\
(0.55)\end{array}$ \\
\hline POST_END $\times$ PILOT & $\begin{array}{c}-0.006 \\
(-0.44) \\
\end{array}$ & $\begin{array}{r}0.011 \\
(0.79) \\
\end{array}$ & $\begin{array}{c}0.008 \\
(0.55) \\
\end{array}$ & $\begin{array}{r}-0.013 \\
(-1.38) \\
\end{array}$ \\
\hline \multicolumn{5}{|l|}{ Control Variables: } \\
\hline LAGSIZE & $\begin{array}{l}0.128^{* * *} \\
(3.84)\end{array}$ & $\begin{array}{l}0.135^{* * *} \\
(3.41)\end{array}$ & $\begin{array}{l}0.112^{* * *} \\
(3.83)\end{array}$ & $\begin{array}{l}0.130^{* * *} \\
(5.21)\end{array}$ \\
\hline$L A G B M$ & $\begin{array}{l}-0.196 * * * \\
(-2.69)\end{array}$ & $\begin{array}{l}-0.136^{*} \\
(-1.69)\end{array}$ & $\begin{array}{l}-0.146^{*} \\
(-1.84)\end{array}$ & $\begin{array}{l}-0.158^{* *} \\
(-2.55)\end{array}$ \\
\hline DLOSS & $\begin{array}{r}0.015 \\
(0.43)\end{array}$ & $\begin{array}{r}0.063 \\
(0.89)\end{array}$ & $\begin{array}{r}-0.020 \\
(-0.69)\end{array}$ & $\begin{array}{l}0.155^{*} \\
(1.94)\end{array}$ \\
\hline ANNRET & $\begin{array}{l}-0.020 \\
(-1.15)\end{array}$ & $\begin{array}{l}-0.022 \\
(-1.11)\end{array}$ & $\begin{array}{l}-0.009 \\
(-0.58)\end{array}$ & $\begin{array}{l}-0.022^{*} \\
(-1.78)\end{array}$ \\
\hline RETVOL & $\begin{array}{l}-1.333 \\
(-0.86)\end{array}$ & $\begin{array}{r}-0.447 \\
(-0.34)\end{array}$ & $\begin{array}{l}-2.304 \\
(-1.62)\end{array}$ & $\begin{array}{l}-0.146 \\
(-0.14)\end{array}$ \\
\hline LITIGRISK & $\begin{array}{r}0.117 \\
(0.58)\end{array}$ & $\begin{array}{r}0.152 \\
(0.77)\end{array}$ & $\begin{array}{r}0.207 \\
(1.02)\end{array}$ & $\begin{array}{r}-0.077 \\
(-0.50)\end{array}$ \\
\hline ANALYCOV & $\begin{array}{r}0.002 \\
(0.68)\end{array}$ & $\begin{array}{r}0.003 \\
(1.22)\end{array}$ & $\begin{array}{r}0.001 \\
(0.33)\end{array}$ & $\begin{array}{r}0.000 \\
(0.13)\end{array}$ \\
\hline INSTOWN & $\begin{array}{r}0.061 \\
(0.69)\end{array}$ & $\begin{array}{l}-0.057 \\
(-0.44)\end{array}$ & $\begin{array}{r}0.036 \\
(0.32)\end{array}$ & $\begin{array}{l}-0.075 \\
(-0.96)\end{array}$ \\
\hline MFHORIZON & $\begin{array}{l}-0.031^{*} \\
(-1.79)\end{array}$ & $\begin{array}{l}-0.079 * * * \\
(-3.29)\end{array}$ & $\begin{array}{l}-0.042^{* *} \\
(-2.28)\end{array}$ & $\begin{array}{l}-0.056^{* * *} \\
(-2.97)\end{array}$ \\
\hline ABSMFE & $\begin{array}{l}-2.192 \\
(-1.49)\end{array}$ & $\begin{array}{l}-2.053 \\
(-1.29)\end{array}$ & $\begin{array}{l}-2.950 \\
(-1.59)\end{array}$ & $\begin{array}{l}-0.568 \\
(-0.50)\end{array}$ \\
\hline ABSMFSURP & $\begin{array}{l}-4.909 * * \\
(-2.33)\end{array}$ & $\begin{array}{l}-8.677^{* * * *} \\
(-2.79)\end{array}$ & $\begin{array}{l}-3.654 \\
(-1.63)\end{array}$ & $\begin{array}{l}-9.186^{* * * *} \\
(-3.67)\end{array}$ \\
\hline Intercept & $\begin{array}{l}-1.049 * * * \\
(-3.52)\end{array}$ & $\begin{array}{l}-1.086^{* * *} \\
(-3.69)\end{array}$ & $\begin{array}{l}-0.902^{* * * *} \\
(-3.29)\end{array}$ & $\begin{array}{l}-1.007^{* * *} \\
(-5.16)\end{array}$ \\
\hline $\begin{array}{l}\text { Firm fixed effects } \\
\text { Quarter fixed effects }\end{array}$ & $\begin{array}{l}\text { Yes } \\
\text { No }\end{array}$ & $\begin{array}{l}\text { Yes } \\
\text { No }\end{array}$ & $\begin{array}{l}\text { Yes } \\
\text { No }\end{array}$ & $\begin{array}{l}\text { Yes } \\
\text { No }\end{array}$ \\
\hline Observations & 2,353 & 1,123 & 1,897 & 1,740 \\
\hline Adjusted $R^{2}$ & 0.240 & 0.229 & 0.248 & 0.242 \\
\hline
\end{tabular}

This table presents results on changes in management forecast precision around the end of the Reg SHO experiment (July 6, 2007). The sample includes 3,476 (3637) quarterly point and range good news and bad news management forecasts released in firm-quarters in the event window $[-4,+3]$ with required data under the traditional (Rogers and Van Buskirk) methodology, where event quarter 0 is the fiscal quarter in which the Reg SHO experiment was terminated. The coefficients on MFHORIZON are multiplied by 100 for exposition. T-statistics reported in parentheses are based on heteroscedasticity robust standard errors clustered by firm. *, **, and *** indicate statistical significance at the $10 \%, 5 \%$, and $1 \%$ levels (two-sided), respectively. The appendix contains the variable definitions. 
TABLE 8

Cross-Sectional Variations in Changes in Bad News Management Forecast Precision around Reg SHO

\begin{tabular}{|c|c|c|c|c|c|c|c|}
\hline \multicolumn{8}{|c|}{ Dependent Variable: PRECISION (Bad News Management Forecasts) } \\
\hline Cross-sectional Variable: & $\begin{array}{c}\text { CEOOPT } \\
\text { (1) }\end{array}$ & $\begin{array}{c}\text { CFOOPT } \\
\text { (2) }\end{array}$ & $\begin{array}{l}\text { SIZE } \\
\text { (3) }\end{array}$ & $\begin{array}{c}\text { FIRMAGE } \\
\text { (4) }\end{array}$ & $\begin{array}{c}\text { NANALYST } \\
\text { (5) }\end{array}$ & $\begin{array}{c}\text { INSTOWN } \\
(6)\end{array}$ & $\begin{array}{c}\text { CHGERC } \\
\text { (7) }\end{array}$ \\
\hline \multicolumn{8}{|c|}{ Panel A: Traditional News Measure } \\
\hline \multirow[t]{2}{*}{ POST } & 0.002 & 0.006 & 0.025 & 0.022 & $0.057^{*}$ & 0.028 & -0.018 \\
\hline & $(0.11)$ & $(0.31)$ & $(1.26)$ & $(1.00)$ & $(1.94)$ & $(1.02)$ & $(-0.88)$ \\
\hline \multirow[t]{2}{*}{$P O S T \times P I L O T$} & -0.008 & 0.023 & $-0.094 * * *$ & $-0.051 *$ & $-0.107 * * *$ & -0.046 & -0.003 \\
\hline & $(-0.33)$ & $(0.87)$ & $(-3.28)$ & $(-1.80)$ & $(-2.82)$ & $(-1.33)$ & $(-0.13)$ \\
\hline \multirow[t]{2}{*}{$C S V A R \times P O S T$} & 0.008 & -0.002 & -0.028 & -0.023 & $-0.095^{*}$ & -0.034 & 0.056 \\
\hline & $(0.29)$ & $(-0.06)$ & $(-1.06)$ & $(-0.69)$ & $(-1.88)$ & $(-0.78)$ & (1.55) \\
\hline \multirow[t]{2}{*}{$C S V A R \times P O S T \times P I L O T$} & -0.047 & $-0.096 * *$ & $0.115^{* * *}$ & 0.036 & $0.145 * *$ & 0.024 & $-0.079 *$ \\
\hline & $(-1.21)$ & $(-2.16)$ & $(2.83)$ & $(0.89)$ & $(2.50)$ & $(0.50)$ & $(-1.74)$ \\
\hline Observations & 4,021 & 3,739 & 5,177 & 5,177 & 5,177 & 5,177 & 3,860 \\
\hline Adjusted $R^{2}$ & 0.260 & 0.261 & 0.240 & 0.237 & 0.243 & 0.237 & 0.245 \\
\hline \multicolumn{8}{|c|}{ Panel B: Rogers and Van Buskirk News Measure } \\
\hline \multirow[t]{2}{*}{ POST } & 0.018 & 0.029 & 0.024 & 0.029 & $0.057 *$ & 0.033 & -0.017 \\
\hline & $(0.76)$ & (1.07) & (1.20) & (1.16) & (1.95) & (1.13) & $(-0.74)$ \\
\hline \multirow[t]{2}{*}{ POST $\times$ PILOT } & -0.009 & 0.023 & $-0.071^{* *}$ & $-0.055^{*}$ & $-0.100 * *$ & -0.048 & 0.005 \\
\hline & $(-0.37)$ & $(0.72)$ & $(-2.41)$ & $(-1.81)$ & $(-2.53)$ & $(-1.37)$ & $(0.22)$ \\
\hline \multirow[t]{2}{*}{$C S V A R \times P O S T$} & -0.004 & -0.024 & -0.014 & -0.022 & -0.082 & -0.030 & $0.081^{* *}$ \\
\hline & $(-0.14)$ & $(-0.71)$ & $(-0.52)$ & $(-0.63)$ & $(-1.58)$ & $(-0.66)$ & $(2.01)$ \\
\hline \multirow[t]{2}{*}{$C S V A R \times P O S T \times P I L O T$} & -0.033 & $-0.088^{*}$ & $0.077 *$ & 0.049 & $0.136^{* *}$ & 0.034 & $-0.097 * *$ \\
\hline & $(-0.79)$ & $(-1.70)$ & $(1.86)$ & (1.12) & $(2.27)$ & $(0.68)$ & $(-1.99)$ \\
\hline Observations & 3,368 & 3,150 & 4,352 & 4,352 & 4,352 & 4,352 & 3,257 \\
\hline Adjusted $R^{2}$ & 0.257 & 0.271 & 0.238 & 0.237 & 0.242 & 0.237 & 0.253 \\
\hline Control variables & Yes & Yes & Yes & Yes & Yes & Yes & Yes \\
\hline Firm fixed effects & Yes & Yes & Yes & Yes & Yes & Yes & Yes \\
\hline Quarter fixed effects & Yes & Yes & Yes & Yes & Yes & Yes & Yes \\
\hline
\end{tabular}

This table presents results from analysis of changes in bad news management forecast precision around the Reg SHO experiment conditioning on seven crosssectional variables (CSVAR): CEO option incentives, CFO option incentives, firm size, firm age, analyst coverage, institutional ownership, and increases in ERC. All cross-sectional variables are measured as average levels over the pre-event window [-8, -1] for each firm. The initial sample for these tests includes 5,177 (4,352) quarterly point and range bad news management forecasts released in firm-quarters in the event window [-8, +7] with required data under the traditional (Rogers and Van Buskirk) methodology, where event quarter 0 is the fiscal quarter in which the Reg SHO experiment was implemented. The final sample size could be reduced in an individual regression due to missing observations in the cross-sectional variable of interest. CEOOPT (CFOOPT) is the scaled decile rank of the incentive ratio for CEO's (CFO’s) options holdings, which is measured as ONEPCT_OPT/(ONEPCT_OPT+SALARY+BONUS). The variable ONEPCT_OPT (or options sensitivity) is 
the dollar change in the value of executive options holdings resulting from a $1 \%$ increase in the firm's stock price. SIZE is the scaled decile rank of the logarithm of the beginning-of-quarter market capitalization. FIRMAGE is the scaled decile rank of the number of years since the firm's CRSP listing date. NANALYS is the scaled decile rank of the number of analysts following the firm in the current quarter. INSTOWN is the scaled decile rank of the percentage of stocks held by institutional investors. CHGERC is the scaled decile rank of the change in ERC around the Reg SHO experiment. For each firm, ERC before (after) the Reg SHO is estimated over 20 quarters before (after) implementation of the experiment, with a minimum of 10 observations. The scaled decile rank is determined by first ranking observations each year into 10 groups from zero to 9, then scaling the ranking by 9 so that the rank variable falls within the zero-to- 1 interval. All the control variables as in Table 4 are included but not reported for conciseness. T-statistics reported in parentheses are based on heteroscedasticity-robust standard errors clustered by firm. *,**, and $* * *$ indicate statistical significance at the $10 \%, 5 \%$, and $1 \%$ levels (two-sided), respectively. The appendix contains the variable definitions. 